\title{
Multiple fluid migration events and REE+Th mineralisation during Alpine metamorphism in the Sopron micaschist from the Eastern-Alps (Sopron area, Western Hungary)
}

\author{
TÖRÖK, Kálmán \\ Magyar Bányászati és Földtani Szolgálat, H-1143 Budapest, Stefánia út 14. \\ e-mail: torok.kalman@mbfsz.gov.hu
}

\section{Fluidum migrációs események és RFF+Th ásványosodás a Soproni Csillámpala alpi metamorfózisa során}

Összefoglalás

Petrográfia, ásványkémiai és fluidumzárvány-vizsgálatok segítségével négy fluidum migrációs eseményt rögzítettünk az alpi metamorfózis során az Alsó-Ausztroalpi-egységbe tartozó Soproni Csillámpala Formációban.

1. Turmalinosodás a metamorfózis csúcsa után nem sokkal $\left(\mathrm{T}=560-610{ }^{\circ} \mathrm{C}, \mathrm{p}=950-1230 \mathrm{MPa}\right)$.

2. A leukofilliteket létrehozó Mg-metaszomatózis, amely nyírási zónák mentén ment végbe a metamorfózis csúcsa után.

3. Lokális monacit, allanit, apatit, florencit, tórit és tórianit dúsulása kvarcerekben, illetve deformációs zónák mentén. A kvarcerekben szén-dioxidot is tartalmazó hiperszalin vizes fluidumzárványokat találtunk, amelyekben Ca, $\mathrm{K}, \mathrm{Na}, \mathrm{Cl}, \mathrm{S}, \mathrm{Mn}$ és ritkaföldfémeket tartalmazó fázisokat észleltünk.

4. A retrográd metamorfózis késői szakaszához köthető másodlagos, kétfázisú, 25-28,5 m/m\% sótartalmú vizes fluidumzárványok, melyek homogenizációs hőmérséklete $229,6-322^{\circ} \mathrm{C}$.

Tárgyszavak: fluidumzárvány, fluidummigráció, geotermo-barometria, RFF+Th ásványosodás, Kelet-Alpok

Abstract

Four fluid migration events have been recorded as having occurred during the Alpine metamorphism in the Sopron micaschist from the Grob gneiss series of the Lower Austroalpine Unit of the Eastern Alps near Sopron. In order to make these recordings mineral chemistry data were collected, and geothermo-barometry and fluid inclusion studies were employed. The four events can be summarised as follows:

1. Tourmaline mineralisation took place in quartz veins and to some extent in the host rock. Similar mineral compositions in the quartz-tourmaline veins and in the host rock show an equilibrium between the fluid and the host rock. Geothermo-barometry indicates temperatures between $560-610{ }^{\circ} \mathrm{C}$ and pressures of $950-1230 \mathrm{MPa}$ for the formation of the quartz-tourmaline veins. These figures are the same as those determined for the $\mathrm{P}-\mathrm{T}$ peak $(\mathrm{T}=560$ and $\left.600{ }^{\circ} \mathrm{C} \mathrm{p}=840-1230 \mathrm{MPa}\right)$.

2. Fluids caused Mg-metasomatism in the shear zones. This fluid invasion resulted in (i) the formation of leucophyllite in the shear zones and (ii) Mg-enrichment of some minerals (chlorite, muscovite, garnet) in the close vicinity of the shear zone. The effect of this fluid was confined to the shear zones and the neighbouring host rock.

3. The rock was infiltrated along the shear zones and quartz veins with $\mathrm{CO}_{2}$-bearing hypersaline fluids during retrograde metamorphism. The presence of this fluid is evidenced by secondary $\mathrm{CO}_{2}$ inclusions and hypersaline aqueous fluid inclusions $\pm \mathrm{CO}_{2}$. The aqueous fluid had high concentrations of $\mathrm{Na}, \mathrm{Ca}, \mathrm{Fe}, \mathrm{Al}, \mathrm{Cl}$ and contained moderate amounts of $\mathrm{Mg}, \mathrm{Zn}, \mathrm{Ti}, \mathrm{K}, \mathrm{Mn}, \mathrm{S}$ and $\mathrm{P}$. This fluid was the carrier of the REE and Th and locally precipitated florencite, monazite, allanite, apatite, thorite and thorianite in the shear zone. Traces of this mineralisation are found in the quartz-tourmaline veins, postdating the tourmaline mineralisation.

4. Late retrograde metamorphic fluid. This is represented by two phase (liquid+vapour) aqueous inclusions in the $\mathrm{NaCl}-\mathrm{CaCl}_{2}-\mathrm{H}_{2} \mathrm{O}$ system, with a total salinity between $25 \%$ and $28.5 \%$ and homogenisation temperatures between $229.6^{\circ} \mathrm{C}$ and $322^{\circ} \mathrm{C}$ 


\section{Introduction}

Metamorphic rocks in the eastern end of the Alps have been studied intensively over the last three decades. The metamorphic conditions were first thought to be upper greenschist - lower amphibolite facies (LELKES-FELVÁRI et al. 1984; KISHÁZI \& IVANCSICS 1987, 1989). Later, highpressure Alpine metamorphism ( $\mathrm{P}=1200-1400 \mathrm{MPa}, \mathrm{T}=$ about $600^{\circ} \mathrm{C}$ ) was reported in the orthogneiss (TÖRÖK 1996, 1998, DEMÉNY et al. 1997). This was followed by the recording of high-pressure Alpine metamorphism with similar $\mathrm{P}-\mathrm{T}$ conditions $\left(\mathrm{P}=1390-1470 \mathrm{MPa}, \mathrm{T}=550-600^{\circ} \mathrm{C}\right)$ for garnet-staurolite-chloritoid-kyanite-bearing micaschist, occurring around Óbrennberg (TÖRÖK 2003). However, the geothermo-barometric results of DRAGANITS (1998) on the Sopron micaschist in the Austrian part of the Sopron area indicated lower pressure conditions $\left(550 \pm 30{ }^{\circ} \mathrm{C}\right.$ and $0.95 \pm 0.15 \mathrm{GPa})$.

Previous petrologic and fluid inclusion studies on orthogneisses and cross-cutting leucophyllites indicated the occurrence of multiple Alpine fluid migration events, with medium salinity brines occurring around the pressure peak. A high salinity, composite $\left(\mathrm{NaCl}, \mathrm{CaCl}_{2} \mathrm{MgCl}_{2}\right.$ etc.) retrograde aqueous fluid — which caused $\mathrm{Mg}$-metasomatism (formation of leucophyllites) — and another fluid with an unknown composition, resulted in minor phosphate mineralisation; the latter involved $\mathrm{Pb}$-bearing goyazite, Mg-rich lazulite and apatite in the gneisses and related leucophyllites (TöRÖK 2001).

The main purpose of the present study is to determine the Alpine metamorphic fluid systems in the Sopron micaschist and associated leucophyllite and compare them with those described in the orthogneiss (TÖRÖK 2001). Textural analysis, mineral chemistry, fluid inclusion studies and geothermobarometry were performed to determine (i) the sequence of minerals in the mineralisations, (ii) the extent of fluid-rock interaction, (iii) the formation conditions of the fluids and (iv) to link the fluid migration history with the metamorphic P-T evolution of the Sopron micaschist.

\section{Geology of the study area}

In the Sopron area metamorphic rocks belong to the Grob Gneiss unit of the Lower Austroalpine nappe system (TollmanN 1977). The main rock types comprise orthogneiss and garnet-bearing chlorite-muscovite schist, which is called Sopron micaschist (Figure 1). The Sopron micaschist was intruded by a granitic precursor rock of the orthogneiss in the Hercynian (KISHÁzI \& IVANCSICS 1985). Subordinately amphibolites, andalusite-sillimanite-biotite schist, kyanite-staurolite-chloritoid, and garnet-bearing and chloritoid-garnet-bearing micaschists also appeared. Kyanite-bearing, Mg-chlorite-muscovite-quartz schists so-called leucophyllites - also emerged in the shear zones, cross-cutting both the gneisses and the micaschists.

The metamorphic history of the area is complex. Andalusite-sillimanite-biotite schist near Óbrennberg was preserved with an exceptional pre-Alpine low-pressure/ high-temperature $\left(\mathrm{P}=240-380 \mathrm{MPa} \mathrm{T}=650-700{ }^{\circ} \mathrm{C}\right) \mathrm{min}-$ eral assemblage (with sillimanite, andalusite, corundum, spinel, garnet and biotite); furthermore, a pre-Alpine medium grade and medium pressure $(\mathrm{P}=860-1060 \mathrm{MPa}$, $\mathrm{T}=615-666^{\circ} \mathrm{C}$ ) overprint occurred (TöRÖK 1999). Most of the rocks of the Sopron area show evidence of an Alpine high-pressure overprint (TöRÖK 1996, 1998, 2001, 2003);

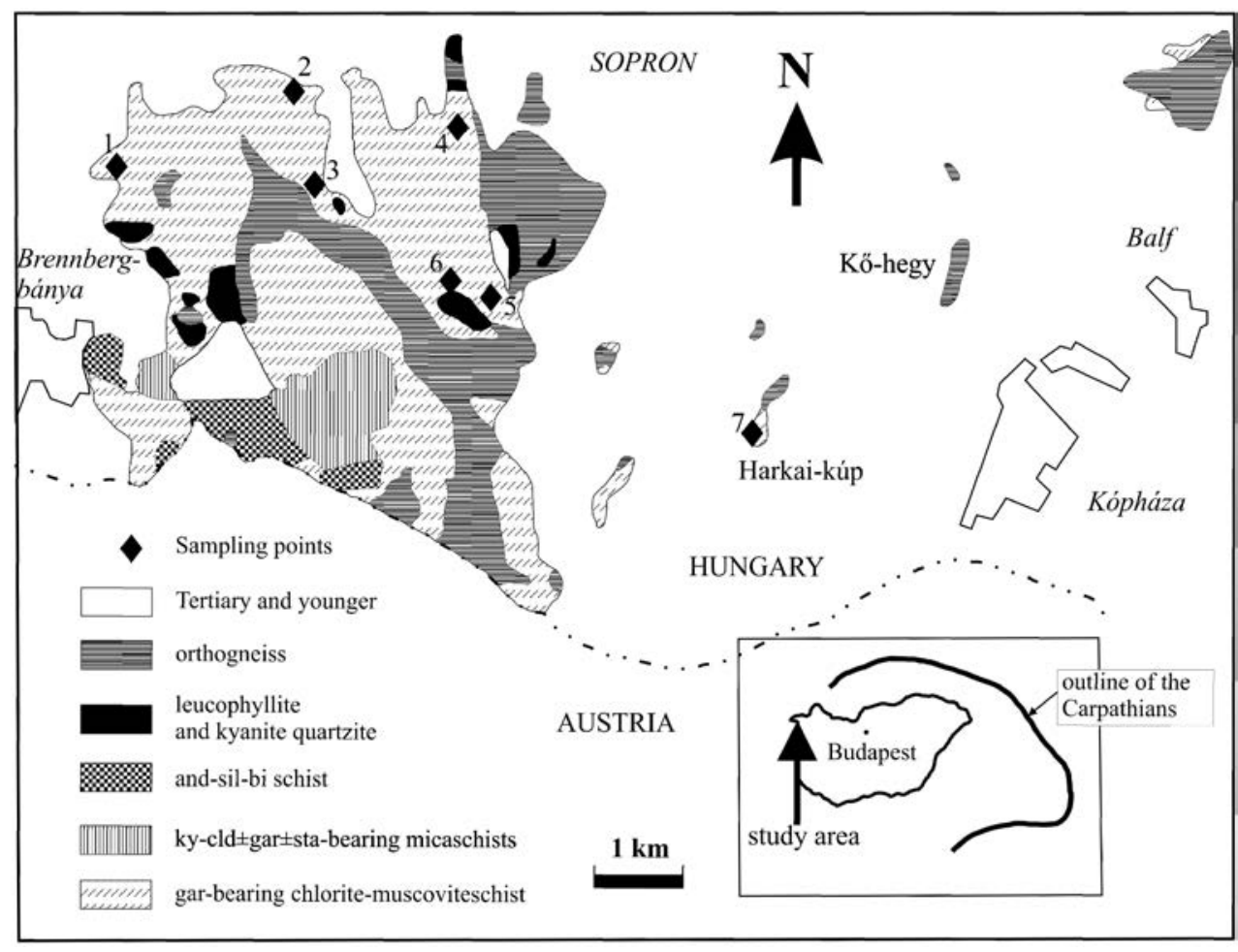

Figure 1. Geological sketch map of the Sopron area after KisHÁZI \& IVANCSICS (1989) with the sampling points (diamonds)

1. Hermes-hegy - micaschist; 2 . Vöröshíd quarry - micaschist; 3 . Tolvaj-árok - quartz-tourmaline vein in micaschist, 4 Gloriette quarry micaschist; 5 Füzes-árok - micaschist; 6. Füzes-árok - leucophyllite with REE and Th mineralisation, 7. Harkai-csúcs - micaschist with quartz-tourmaline veins

1. ábra. Vázlatos földtani térkép a Sopron környéki metamorfitokról KISHÁZI ÉS IVANCSICS (1989) nyomán. A mintavételi pontokat rombuszokkal jelöltük

1. Hermes-hegy - csillámpala; 2. Vöröshidi-köfejtó - csillámpala; 3. Tolvaj-árok - kvarc-turmalinér csillámpalában, 4 Gloriette köfejtö - csillámpala; 5 Füzes-árok - csillámpala; 6. Füzes-árok - leukofillit RFF+Th ásványosodással, 7. Harkai-csúcs - csillámpala kvarc-turmalin erekkel 
however, this is not the case with the andalusite-sillimanitebiotite schist. The oldest age of the rocks was determined on the basis of the biotites of the andalusite-sillimanite-biotite schist by BALOGH \& DUnKL (2005); they used a K-Ar method and found them to be from the Carboniferous (328.5-319.5 Ma). A similar age (about $300 \mathrm{Ma}$ ) was given by NAGY et al. (2002) using a monazite Th-U-total Pb age determination. This was followed by a Permo-Triassic (272$236 \mathrm{Ma}) \mathrm{HT} / \mathrm{LP}$ metamorphism determined from the same rock type (BALOGH \& DunKL 2005). The age of the Alpine high-pressure metamorphism was between 76 and $71 \mathrm{Ma}$ (BALOGH \& DUNKL 2005). Similar ages were determined in other rocks from the neighbouring Austroalpine units (e.g. THÖNI 1999, SCHUSTER \& THÖNI 2001). So far the metamorphic rocks from the Sopron area are the only Alpine high pressure ones to have been recognised in the Lower Austroalpine Unit in the eastern part of the Eastern Alps. Other Alpine high-pressure rocks - namely, eclogites - were described only from the Middle Austroalpine Koralpe, Saualpe and the Sieggraben unit (e.g. MiLLER 1990, GREGUREK et al. 1997, Neubauer et al. 1999).

Leucophyllites (Mg-chlorite-muscovite-quartz schists with or without kyanite) are special rock types occurring in the Eastern Alps (Prochaska et al. 1997 and references therein). These occur as metasomatic veins cross-cutting both gneisses and micaschists. The formation of leucophyllites in the Sopron area has been attributed to metasomatism, caused by highly saline aqueous fluids present during the Alpine retrograde metamorphism $(\mathrm{P}=700-1050$ $\mathrm{MPa}$, $\mathrm{T}=550$ $600{ }^{\circ} \mathrm{C}$; TÖRÖK 2001). For the formation of leucophyllites from the Austrian part ProchasKa et al. (1997) obtained lower $\mathrm{P}-\mathrm{T}$ conditions $\left(\mathrm{T}=450-500{ }^{\circ} \mathrm{C}, \mathrm{P}=800-1000 \mathrm{MPa}\right)$ on the basis of stable isotope and fluid inclusion data.

\section{Sample description}

The studied Sopron micaschist consists of mainly quartz, chlorite, muscovite, paragonite, garnet, and \pm biotite \pm chloritoid \pm plagioclase. The schistosity is marked by large (up to $300 \mu \mathrm{m}$ ) chlorite and muscovite \pm biotite flakes. Fine-grained albite-muscovite-paragonite-quartz aggregates occur frequently and are interpreted as pseudomorphs after staurolite. These pseudomorphs occasionally contain biotite, monazite and post-tectonic chloritoid. Chloritoid with chlorite was also found as inclusions in garnet. Garnet occurs as large (up to 3-4 $\mathrm{mm}$ ) rounded, and zoned porphyroblasts or as small post-tectonic idioblasts. Large porphyroblasts contain mostly quartz inclusions but some of them may also contain chlorite, chloritoid, biotite, ilmenite and tourmaline. Biotites have been more or less altered to chlorite. Unaltered biotite can be found only in the less retrograded samples and sometimes as an inclusion in garnet. Tourmaline, monazite, allanite, apatite, zircon, rutile and ilmenite occur as accessories. Amongst the accessories, tourmaline is the most abundant and can be quite frequent (up to $5-8 \%$ ) in some samples.

Tourmaline and rutile-bearing quartz veins can also be found associated with the Sopron micaschist. These veins contain quartz and tourmaline \pm muscovite \pm chlorite \pm garnet \pm plagioclase \pm rutile. Tourmaline and garnet grew together, as is indicated by the tourmaline-garnet intergrowths. Most of the quartz-tourmaline veins are highly deformed, and this is demonstrated by the broken tourmaline grains and the ribbon-structured quartz. The quartztourmaline vein from the Füzes-árok contains allanite; this allanite fills the space between the tourmaline grains and idioblastic, undeformed prismatic apatite. These apatites may contain small $(2-10 \mu \mathrm{m})$ anhedral allanite inclusions. SPRÁNITZ et al. (2018) described and characterised several types of tourmaline-rich rock types related to the gneisses, micaschists and leucophyllites present in the Sopron Mts.

Leucophyllite samples from the Füzes-árok contain three types of REE, Th and P mineralisations; these were first described by FAZEKAS et al. (1975).

1. Florencite mineralisation in leucophyllite. Florencite contains variable amounts of $\mathrm{Th}$; this produces either inhomogeneous spotted arrangements (Figure 2A) or spectacular zoning (Figure 2B) in back-scattered electron images. Cheralite inclusions and cross-cutting veins also appear in florencite (Figure 2A, B). FAZEKAS et al. (1975) also described lazulite as part of this assemblage.

2. Monazite-apatite ( \pm thorite and thorianite) mineralisation in paragonite-bearing leucophyllite. Monazite forms skeletal crystals which have been overgrown by apatite (Figure 2C). These skeletal crystals mimic the shape of the zoned florencite. Both monazite and apatite overgrow the rock-forming kyanite and $\mathrm{Mg}$-chlorite. The textural relationship between the two minerals suggests that the monazite formed first. Thorite and thorianite can be found as inclusions in monazite but are rare in apatite. The mineral composition of the host rock differs from the first type, because most of the muscovites have been replaced by paragonite (Figure 2D). FAZEKAS et al. (1975) described monazite as having partially or fully replaced florencite.

3. Allanit-apatite mineralisation in quartz-tourmaline veins from the Füzes-árok. Allanite fills the space between tourmaline grains (Figure 2E). Allanite can also be observed as an inclusion in idioblastic apatite crystals, which indicates that the apatite was the last to be crystallised. A summary of the sequence of minerals in REE- and Thmineralised shear zones and quartz-tourmaline veins is given shown in Table I.

\section{Analytical methods}

The chemistry of the rock-forming minerals was determined by an AMRAY 1810I scanning electron microscope equipped with an EDS detector. (This was carried out at the Department of Petrology and Geochemistry, Eötvös 

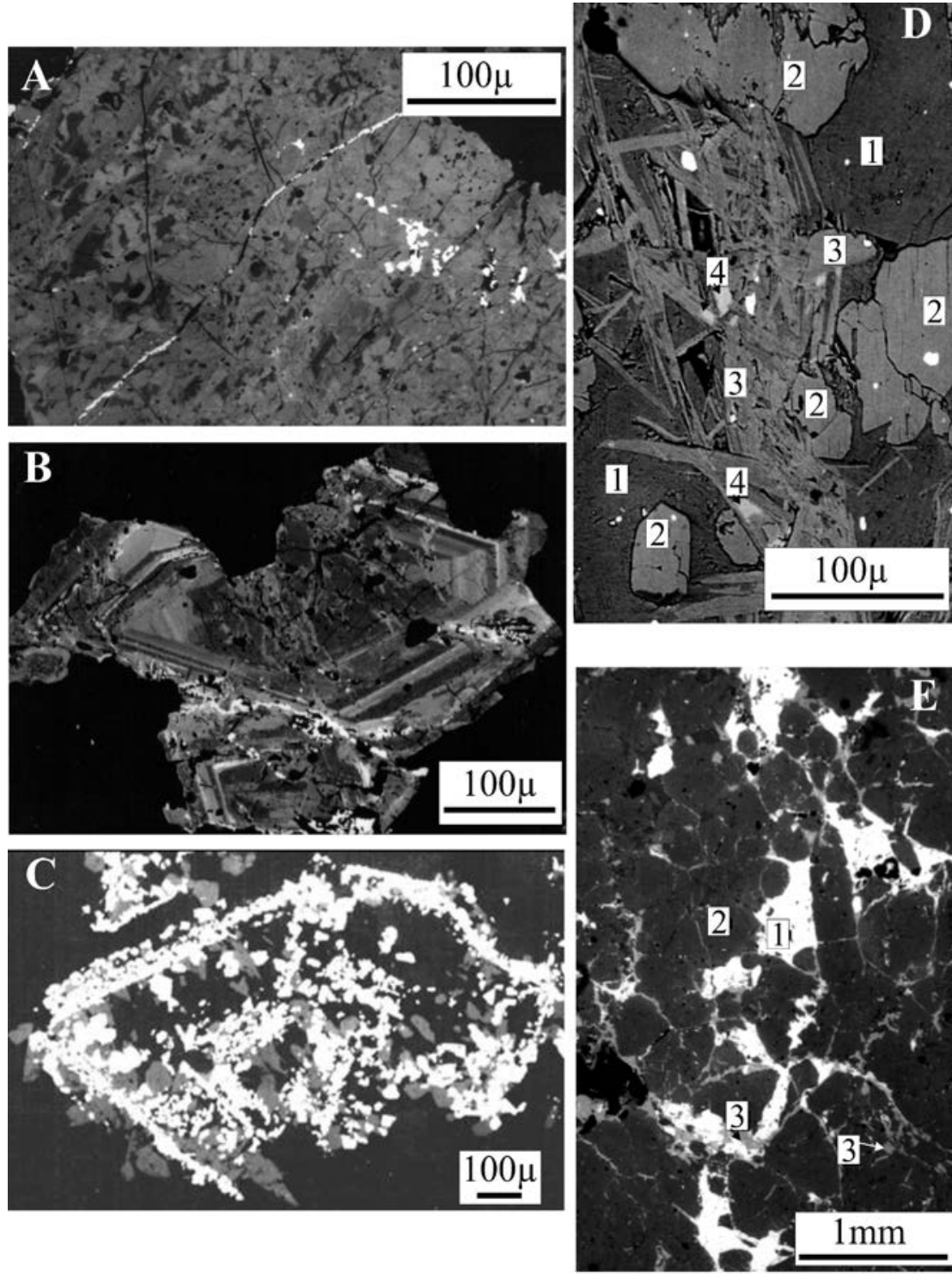

Figure 2. Back-scattered electron images of the relevant mineral and rock textures

A) Inhomogeneous florencite with cheralite inclusions (white spots) and veins from a florencite-type mineralisation of the leucophyllite; B) Zoned florencite with an inhomogeneous core cut by cheralite veins from a florencite-type mineralisation of the leucophyllite; C) Skeletal monazite (white) overgrown by apatite (grey) from the monazite-apatitetype mineralisation of the paragonite-bearing leucophyllite; D) Muscovite relics in paragonite from the monazite-apatitetype mineralisation of the paragonite-bearing leucophyllite. 1 - Mg-chlorite, 2 - kyanite, 3 - paragonite, 4 - muscovite; E) Allanite, filling the space between tourmalines from a quartz-tourmaline vein. 1 - allanite, 2 - tourmaline, 3 - chlorite

2. ábra. A fontosabb ásvány és közetszöveti jelenségek visszaszórt elektronképeken

A) Inhomogén florencit cheralit zárványokkal (világos) és cheralit érrel leukofillitböl; B) Zónás florencit inhomogén maggal és cheralit érrel leukofillitből; C) Monacit vázkristály (világos), melyre apatit nö (szürke)paragonitos leukofillitben; D) Muszkovit reliktum paragonitban a monacit-apatit ásványosodás mellékközetében a paragonitos leukofillitben . 1 . Mgklorit, 2. kianit, 3. paragonit, 4. muszkovit; E) A turmalin szemcsék közötti teret kitöltö allanit kvarc-turmalin érböl. 1. allanit, 2. turmalin, 3. klorit

University, Budapest.) Natural and synthetic minerals were used as standards and ZAF correction was used during the calculation of mineral compositions.

Fluid inclusion measurements were made on a ChaixMeca heating-freezing stage (this took place at the Department of Mineralogy of Eötvös Loránd University, Budapest). The equipment was calibrated with synthetic fluid inclusions and pure chemicals of known composition.

\section{Mineral chemistry}

\section{White micas}

Chemically, white micas are divided into paragonite and muscovite. Paragonite occurs in the albite-paragonite-muscovite aggregates or replaces muscovite in the paragonitebearing leucophyllite with monaziteapatite type mineralisation. The latter has higher $\mathrm{Mg} /(\mathrm{Mg}+\mathrm{Fe})$ ratios than those in the albite-paragonite-muscovite aggregates (Figure 3).

The Si-content of muscovites from the Sopron micaschist varies between 6.18 and $6.54 \mathrm{Si}$ atoms p.f.u. with $\mathrm{Mg} / \mathrm{Mg}+\mathrm{Fe}$ values between 0.52 and 0.67 (Figure 3). The $\mathrm{Si}$ content and $\mathrm{Mg} / \mathrm{Mg}+\mathrm{Fe}$ values of muscovites in the quartz-tourmaline veins also fit in this range (6.24-6.44 $\mathrm{Si}$ atoms p.f.u. and $0.54-0.64$, respectively). The maximum $\mathrm{Si}$ content of the muscovites is much lower than that in the surrounding orthogneisses (7.03 a.p.f.u.).

Muscovites in the mineralised samples of the paragonite-bearing leucophyllite differ chemically from those in the Sopron micaschist. The Si-content of muscovite relics in the paragonite-bearing leucophyllite with monazite-apatite mineralisation tends to be lower than that of the Sopron micaschist. It falls in the range between 6.01 and $6.25 \mathrm{Si}$ atoms p.f.u. (Figure 3) at appreciably higher $\mathrm{Mg} / \mathrm{Mg}+\mathrm{Fe}$ values: i.e. between 0.82 and 0.96 . These $\mathrm{Mg} / \mathrm{Mg}+\mathrm{Fe}$ values are similar to those of the muscovites of unmineralised leucophyllites from other micaschists and gneisses of the Sopron-area. (Figure 3). Representative white mica analyses from all rock types are shown in Table II.

\section{Plagioclase}

Plagioclase in the Sopron micaschists ranges from almost pure albite $\left(\mathrm{An}_{1.7-2.4}\right)$ in the plagioclase-paragonite-muscovite aggregates, to oligoclase (up to $\mathrm{An}_{12.7}$ ) when in contact with garnet. Plagioclase in the quartz tourmaline veins is albitic $\left(\mathrm{An}_{1.1-8.3}\right)$ when in contact with garnet. The K-feldspar component is lower than $1 \%$. Representative plagioclase analyses are shown in Table II. 
Table I. Relative ages of minerals in the mineralised shear zones and veins (leucophyllite, paragonite-bearing leucophyllite and quartz-tourmaline veins)

I. táblázat. Az ásványosodott zónákban (leukofillit, paragonitos leukofillit, kvarcturmalin ér) talált ásványok egymáshoz viszonyított képzödési ideje

\begin{tabular}{|l|c|c|c|c|c|c|}
\hline & 1 & 2 & 3 & 4 & 5 & 6 \\
\hline Mg-chlorite & & + & & & & \\
Kyanite & & + & & & & \\
Muscovite & + & + & & & & \\
Paragonite & & & & + & & \\
Florencite & & & + & & & + \\
Apatite & & & & & & + \\
Monazite & & & & + & & \\
Allanite & & & & & + & \\
Tourmaline & + & & & & & \\
Garnet & + & & & & & \\
Plagioclase & + & & & & & \\
Chlorite & + & & & & & \\
\hline
\end{tabular}

\section{Garnet}

Garnets in the Sopron micaschist occur in two different generations. The older one in the cores of some garnets has sharp contacts towards the overgrowth (Figure 4A); this is shown by the abrupt increase in grossular and decrease in almandine towards the rim. The composition of this older

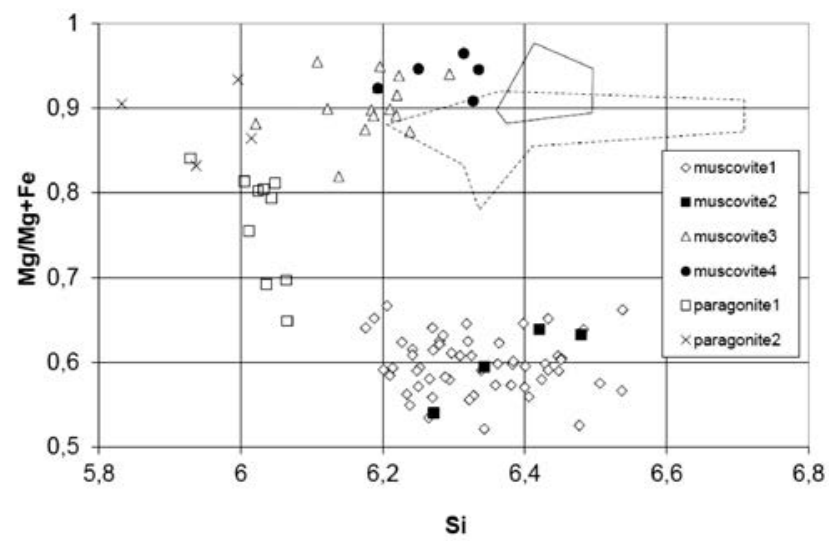

Figure 3. $\mathrm{Si} \mathrm{vs.} \mathrm{Mg} / \mathrm{Mg}+\mathrm{Fe}$ of white micas from the studied rocks

Legend: muscovite 1 - muscovite in the garnet-bearing chlorite-muscovite schist; muscovite2 - muscovite in the quartz-tourmaline veins; muscovite3 - muscovite relics in the paragonite-bearing leucophyllite related with monazite-apatite type mineralisation; muscovite 4 - muscovite in the leucophyllite from Füzesárok, related with florencite-type mineralisation; paragonite 1 - paragonite in the muscovite-paragonite-albite aggregates in the Sopron micaschist; paragonite2 - paragonite in the leucophyllite related with monazite-type mineralisation

The area with dashed borders shows the compositional range of muscovites from leucophyllites in the gneisses (ТӧвӧK 2001). The other area with full borders shows the compositional range of muscovites in leucophyllite in the micaschists near Óbrennberg (ТӧRÖK 2003)

3. ábra. A vizsgált fehér csillámok összetétele Si-Mg/Mg+Fe diagramon muszkovitl - muszkovit a gránátos klorit-muszkovitpalából; muszkovit2 - kvarc-turmalin érból; muszkovit3 - reliktumok a paragonitos leukofillitben; muszkovit4 - a florencites ásványosodást hordozó füzes-árki leukofillitből; paragonit1 - muszkovit-paragonit aggregátumokból a gránátos klorit-muszkovitpalából; paragonit 2 - a monacitos ércesedést hordozó leukofillitböl

A szaggatott vonallal jelölt terület a gneiszekben levö leukofillitek muszkovitjainak, az egybefüggö vonallal jelölt pedig az Óbrennberg környéki csillámpalákban levö leukofillitek muszkovitjainak összetételét mutatja
Table II. Representative analyses of white micas and plagioclase. Cation numbers are on the basis of $22 \mathrm{O}$ for micas and $8 \mathrm{O}$ for plagioclase

II. táblázat. A fehér csillámok és plagioklászok reprezentativ összetétele. A kationszámokat a csillámok esetén 22, a plagioklász esetén 8 oxigénre számoltuk

\begin{tabular}{ccccccccrr}
\hline & 1 & 2 & 3 & 4 & 5 & 6 & 7 & 8 & 9 \\
$\mathrm{SiO}_{2}$ & 48.9 & 47.29 & 46.72 & 48.11 & 47.35 & 48.65 & 65.19 & 66.34 & 67.97 \\
$\mathrm{Al}_{2} \mathrm{O}_{3}$ & 30.94 & 33.91 & 39.1 & 32.52 & 39.28 & 33.43 & 21.29 & 21.1 & 19.87 \\
$\mathrm{TiO}_{2}$ & 0.27 & 0.28 & b.d. & 0.15 & 0.1 & 0.11 & b.d & b.d & b.d \\
$\mathrm{FeO}^{\circ}$ & 1.83 & 1.71 & 0.25 & 1.73 & 0.14 & 0.2 & b.d & b.d & b.d \\
$\mathrm{MgO}^{2}$ & 2.01 & 1.53 & 0.6 & 1.71 & 0.49 & 2.34 & b.d & b.d & b.d \\
$\mathrm{Na}_{2} \mathrm{O}$ & 1.26 & 1.29 & 7.1 & 1.45 & 6.79 & 0.38 & 10.56 & 10.73 & 11.47 \\
$\mathrm{~K}_{2} \mathrm{O}$ & 9.23 & 9.4 & 0.96 & 8.67 & 1.69 & 9.76 & b.d. & 0.1 & b.d. \\
$\mathrm{CaO}$ & b.d. & b.d. & b.d. & b.d. & 0.36 & b.d. & 2.39 & 1.76 & 0.23 \\
$\mathrm{Sum}$ & 94.44 & 95.41 & 94.73 & 94.34 & 96.2 & 94.87 & 99.43 & 100.03 & 99.54 \\
$\mathrm{Si}$ & 6.54 & 6.27 & 6.01 & 6.42 & 6.02 & 6.42 & 2.88 & 2.91 & 2.98 \\
$\mathrm{Al}$ & 4.88 & 5.3 & 5.92 & 5.11 & 5.88 & 5.2 & 1.11 & 1.09 & 1.03 \\
$\mathrm{Ti}$ & 0.03 & 0.03 & 0.0 & 0.02 & 0.01 & 0.01 & 0.0 & 0.0 & 0.0 \\
$\mathrm{Fe} 2$ & 0.21 & 0.19 & 0.03 & 0.19 & 0.02 & 0.02 & 0.0 & 0.0 & 0.0 \\
$\mathrm{Mg}$ & 0.4 & 0.3 & 0.12 & 0.34 & 0.09 & 0.46 & 0.0 & 0.0 & 0.0 \\
$\mathrm{Na}$ & 0.33 & 0.33 & 1.77 & 0.38 & 1.67 & 0.1 & 0.91 & 0.91 & 0.98 \\
$\mathrm{~K}$ & 1.57 & 1.59 & 0.16 & 1.48 & 0.27 & 1.64 & 0.0 & 0.01 & 0.0 \\
$\mathrm{Ca}$ & 0.0 & 0.0 & 0.0 & 0.0 & 0.05 & 0.0 & 0.11 & 0.08 & 0.01 \\
$\mathrm{Sumcat}$ & 13.95 & 14.01 & 14.0 & 13.93 & 14.01 & 13.84 & 5.01 & 5.0 & 4.99 \\
\hline
\end{tabular}

Legend: b.d.- below detection, $\mathrm{FeO}$ * total iron oxide expressed as $\mathrm{FeO}$

1. Muscovite from the garnet-bearing chlorite-muscovite schist; 2 . Fine-grained muscovite from a muscovite-paragonite-albite aggregate from the garnet-bearing chlorite-muscovite schist; 3. Fine-grained paragonite from the same place as " 2 "; 4 . Muscovite from a garnet, chlorite and plagioclase-bearing quartz-tourmaline vein; 5. Paragonite from the leucophyllite; 6 . Muscovite from the leucophyllite; 7. Plagioclase rim in contact with garnet from the garnet-bearing chlorite-muscovite schist; 8 . Plagioclase rim in contact with garnet from a quartz-tourmaline vein; 9. Plagioclase rim in the garnet from the quartztourmaline vein.

Jelmagyarázat: b.d. - kimutatási határ alatt, $\mathrm{FeO}$ - az összes vasat $\mathrm{FeO}$ formájában adtuk meg.

1. Muszkovit a gránátos klorit-muszkovitpalából: 2. Finom szemcsés muszkovit a gránátos klorit-muszkovitpalában található muszkovit-paragonit-albit csomókból; 3. Finomszemcsés paragonit ugyanonnan, mint a „2”; 4. muszkovit a gránátot, plagioklászt és kloritot is tartalmazó kvarc-turmalinérböl; 5. Paragonit leukofillitböl; muszkovit 6. leukofillitböl 7. Gránáttal kontaktusban levö plagioklász szegélye a gránátos klorit-muszkovitpalából; 8. Gránáttal kontaktusban levö plagioklász szegélye kvarc-turmalinérböl; 9. Gránátban zárványként levö plagioklász szegélyekvarc-turmalinérböl.

garnet generation $\left(\mathrm{Alm}_{77-79.5} \mathrm{Gro}_{3.2-5} \mathrm{Spe}_{8.2-10.2} \mathrm{Py}_{7.8-9.6} \mathrm{Adr}_{0-2.6}\right)$ is very close to that of the Ca-poor pre-Alpine garnet rims (Figure 5) from the andalusite-sillimanite-biotite schist of the Kovács-árok (TöRÖK 1999).

The composition and zoning of the young, Ca-rich rims - interpreted as an Alpine overgrowth - depends on whether plagioclase is present or absent in the rock during the growth of garnet.

1. When plagioclase is present in the sample the garnets have a relatively spessartine-rich core with an intermediate grossular content $\left(\mathrm{Alm}_{66.7-73.8} \mathrm{Gro}_{8.4-13} \mathrm{Spe}_{9,1-15.8} \mathrm{Py}_{7.2-8} \mathrm{Adr}_{0-4.5}\right)$. Chloritoid and chlorite inclusion-bearing cores (Figure $4 B$ ) are the richest in spessartine. The grossular component increases and the spessartine and almandine component decreases $\left(\mathrm{Alm}_{65.5-70.5} \mathrm{Gro}_{16.3-20.7} \mathrm{Spe}_{2.8-6.2} \mathrm{Py}_{6.2-8} \mathrm{Adr}_{0-5.3}\right)$ towards the rim. After this zone grossular and spessartine decrease towards the rim, while the almandine component increases. All rims are more calcic in the presence of plagio- 


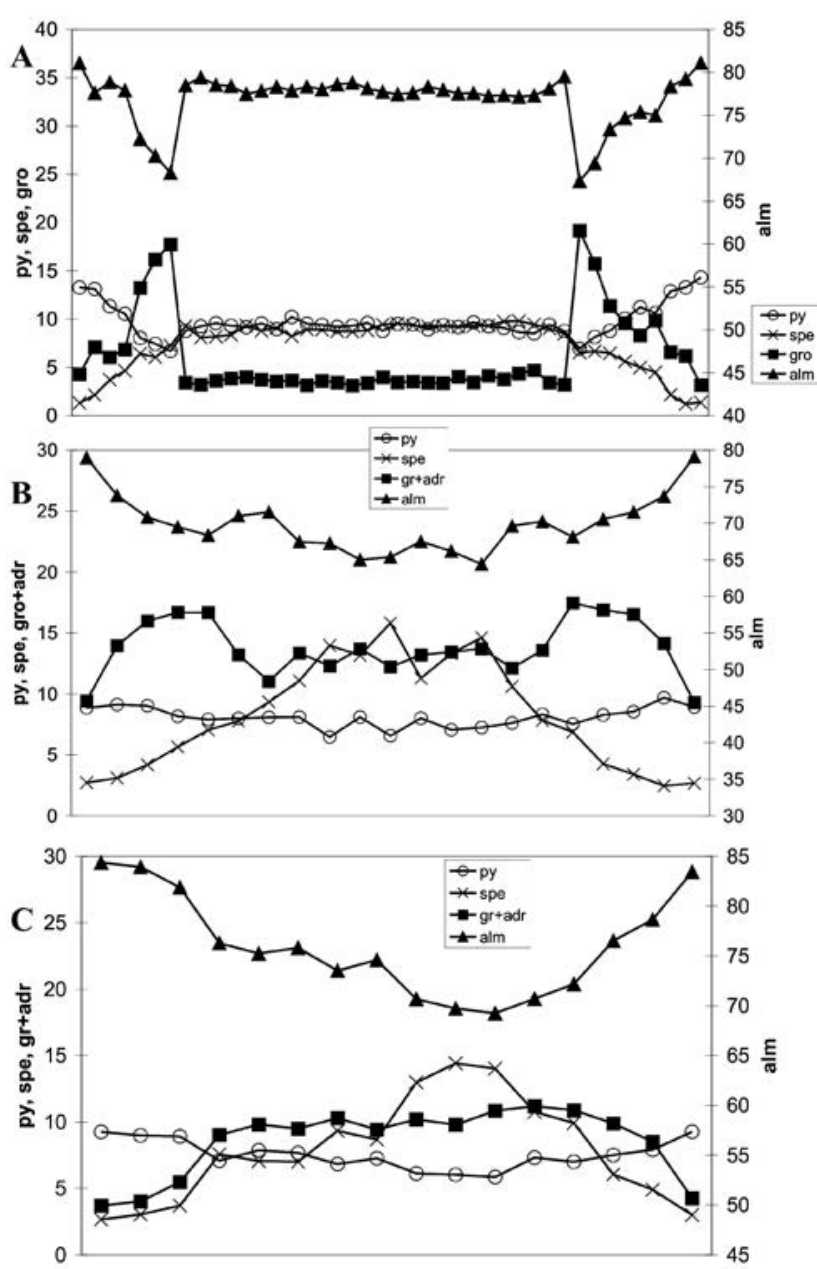

Figure 4. A) Garnet zoning from a plagioclase-free, garnet-bearing chloritemuscovite schist with a pre-Alpine core and an Alpine rim. Dimension of the profile: $0.5 \mathrm{~mm}$. B) Zoning of a garnet in association with plagioclase from the garnet-bearing chlorite-muscovite schist. The core of this garnet contains chloritoid and chlorite inclusions. Dimension of the profile: $370 \mu \mathrm{m}$. C) Garnet zoning from a plagioclase-free, garnet-bearing, chlorite-muscovite schist with a spessartine-rich and grossular-poor core. Dimension of the profile: $230 \mu \mathrm{m}$

4. ábra. A) Pre-alpi magvú, alpi szegélyü gránát zónássága plagioklászmentes gránátos klorit-muszkovitpalából. A gránát átméróje $0,5 \mathrm{~mm}$. B) Zónás gránát plagioklászt tartalmazó gránátos klorit-muszkovitpalából. A gránát magjában klorit-és kloritoidzárványok figyelhetők meg. A gránát átméröje $370 \mu m$.C) Zónás gránát plagioklás mentes gránátos klorit-muszkovitpalából szpesszartingazdag és grosszulárszegény maggal. A gránát átméröje $230 \mu \mathrm{m}$

clase $\left(\mathrm{Alm}_{71.6-79.5} \mathrm{Gro}_{8.2-17.7} \mathrm{Spe}_{1.5-3.3 .} \mathrm{Py}_{8.3-10.1} \mathrm{Adr}_{0-2.3}\right)$, rather than less calcic (as is the case with $\mathrm{Alm}_{84.3-81.1} \mathrm{Gro}_{3.7-4.3} \mathrm{Spe}_{1.3-2.7}$ $\left.\mathrm{Py}_{9.3-13.3}\right)$.

2. When plagioclase is absent, two types of Alpine garnet zoning can be observed, with different core compositions but similar rims (Figure 5). The main zoning trends - namely, with decreasing grossular and spessartine content, and increasing almandine and pyrope content from core to rim are the same as in the first case. The first type (Figure $4 A$ ) has a core composition $\left(\mathrm{Alm}_{67.3} \mathrm{Gro}_{19.2} \mathrm{Spe}_{6.5} \mathrm{Py}_{7}\right)$ comparable to the high-grossular intermediate zone of garnets (which coexists with plagioclase), while the second one (Figure 4C) has a spessartine-rich and grossular-poor core $\left(\mathrm{Alm}_{69.3}\right.$

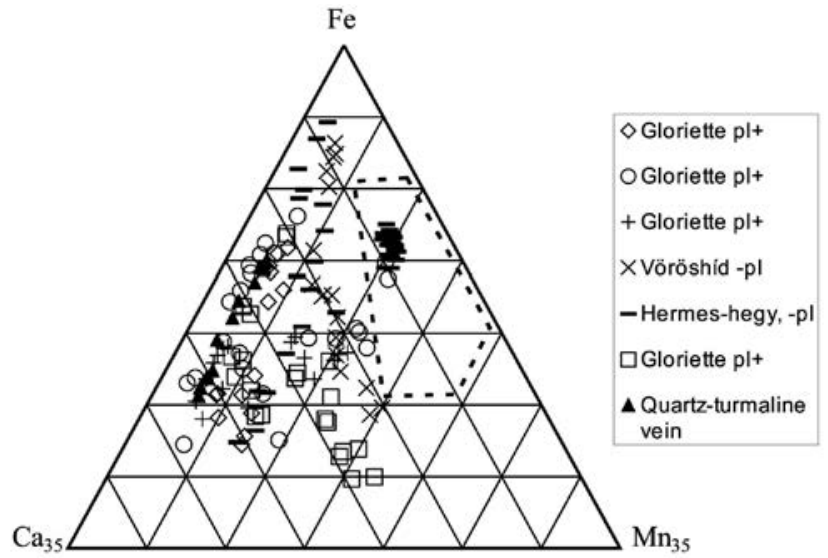

Figure 5. Garnet compositions in the Fe-Ca35-Mn35 triangle in the garnetbearing, chlorite-muscovite schist samples and quartz-tourmaline veins

The different symbols show traverses from different garnets. The area marked with broken lines shows the composition of pre-Alpine garnets from the andalusite-sillimanite-biotite schist of the Kovács-árok, near Óbrennberg

5. ábra. A gránátos klorit-muszkovitpalából és a kvarc-turmalinerekböl származó gránátok összetétele a Fe-Ca35-Mn35 háromszög diagramban

A különbözö jelek, különbözó szemcsékben mért profilokat mutatják. A szaggatott vonallal jelölt terïlet az Óbrennbergi andaluzit-sillimanit-biotit csillámpalában mért pre-alpi gránátok összetételét mutatja

$\left.\mathrm{Gro}_{6.8} \mathrm{Spe}_{14.0} \mathrm{Py}_{5.9} \mathrm{Adr}_{4.0}\right)$. The rim compositions are similar $\left(\mathrm{Alm}_{81.1} \mathrm{Gro}_{4.3} \mathrm{Spe}_{1.3} \mathrm{Py}_{13.3}\right.$ and $\left.\mathrm{Alm}_{84.3} \mathrm{Gro}_{3.7} \mathrm{Spe}_{2.7} \mathrm{Py}_{9.3}\right)$.

The composition of garnets in the quartz-tourmaline veins is similar to that of the garnets in the Sopron micaschist; the latter coexists with plagioclase without the spessartine-rich core. The zoning trend is simple with decreasing grossular and increasing almandine (core: $\mathrm{Alm}_{71.2} \mathrm{Gro}_{19.6} \mathrm{Spe}_{2.6} \mathrm{Py}_{6.6}$, rim: $\left.\mathrm{Alm}_{76.8} \mathrm{Gro}_{12.7} \mathrm{Spe}_{2.4} \mathrm{Py}_{8.1}\right)$. Representative garnet analyses are shown in Table III.

\section{Biotite, chlorite, chloritoid}

Biotites occur in less retrograded samples. $\mathrm{Fe} / \mathrm{Fe}+\mathrm{Mg}$ (between 0.52 and 0.6) and $\mathrm{Ti}$ (between 0.14 and 0.21 a.p.f.u.) ratios are restricted compared to their Al4 content (between 2.23 and 2.64 a.p.f.u.). Representative biotite analyses are shown in Table IV.

Chlorite compositions depend on rock types. Magnesian chlorites $(\mathrm{Mg} / \mathrm{Mg}+\mathrm{Fe}=0.92)$ were found in the leucophyllites. Chlorites of the Sopron micaschist and tourmaline-quartz veins are richer in $\mathrm{Fe}$ with $\mathrm{mg \#}$, the ratios being between 42 and 54, and 38 and 41,respectively (Table IV).

Chloritoids were found only in the Sopron micaschists. $\mathrm{The} \mathrm{Mg} / \mathrm{Fe}$ ratio ranges between 0.171 and 0.303 (Table IV).

\section{Geothermo-barometry}

Several methods were used to obtain estimates for the $\mathrm{P}-$ $\mathrm{T}$ conditions. In most cases garnet rims were measured on the basis of the contacting assemblage. Biotite inclusions in high-Ca garnet zones, and a chlorite inclusion in the Mn and 
Table III. Representative garnet analyses from the the garnet-bearing chloritemuscovite schist and from the quartz-tourmaline vein. Garnet cation numbers are calculated on the basis of $12 \mathrm{O}$

III. táblázat. Reprezentatív gránát elemzések agránátos klorit-muszkovitpalából és a kvarc-turmalinérböl. A gránát kationszámokat 12 oxigénre számoltuk

\begin{tabular}{cccccccccc}
\hline & 1. & 2. & 3. & 4. & 5. & 6. & 7. & 8. & 9. \\
$\mathrm{SiO}_{2}$ & 37.35 & 37.45 & 37.7 & 36.98 & 36.75 & 36.95 & 37.59 & 38.67 & 37.41 \\
$\mathrm{Al}_{2} \mathrm{O}_{3}$ & 20.75 & 20.89 & 20.92 & 20.41 & 20.21 & 20.51 & 21.21 & 21.63 & 21.26 \\
$\mathrm{MgO}$ & 2.04 & 2.19 & 1.54 & 2.2 & 1.48 & 1.82 & 1.78 & 1.62 & 2.24 \\
$\mathrm{Fe} 0^{*}$ & 34.9 & 32.41 & 30.96 & 37.53 & 31.37 & 29.86 & 34.11 & 30.79 & 34.24 \\
$\mathrm{CaO}$ & 3.2 & 5.69 & 7.17 & 1.37 & 3.34 & 4.48 & 3.92 & 6.61 & 1.09 \\
$\mathrm{MnO}$ & 1.43 & 1.26 & 1.67 & 1.31 & 6.22 & 5.35 & 1.02 & 1.11 & 3.45 \\
$\mathrm{Sum}:$ & 99.67 & 99.89 & 99.96 & 99.8 & 99.37 & 98.97 & 99.63 & 100.43 & 99.69 \\
$\mathrm{Si}$ & 3.02 & 3.01 & 3.02 & 3.01 & 3.01 & 3.01 & 3.03 & 3.06 & 3.02 \\
$\mathrm{Al}$ & 1.98 & 1.98 & 1.98 & 1.96 & 1.95 & 1.97 & 2.01 & 2.02 & 2.03 \\
$\mathrm{Mg}$ & 0.25 & 0.26 & 0.18 & 0.27 & 0.18 & 0.22 & 0.21 & 0.19 & 0.27 \\
$\mathrm{Fe} 2$ & 2.36 & 2.18 & 2.08 & 2.56 & 2.15 & 2.04 & 2.3 & 2.04 & 2.31 \\
$\mathrm{Ca}$ & 0.28 & 0.49 & 0.62 & 0.12 & 0.29 & 0.39 & 0.34 & 0.56 & 0.09 \\
$\mathrm{Mn}$ & 0.1 & 0.09 & 0.11 & 0.09 & 0.43 & 0.37 & 0.07 & 0.07 & 0.24 \\
$\mathrm{Sumcat}$ & 7.99 & 8.0 & 7.99 & 8.01 & 8.01 & 8.0 & 7.96 & 7.93 & 7.96 \\
$\mathrm{Adr}$ & 0.0 & 0.27 & 0.0 & 1.03 & 2.15 & 0.21 & 0.11 & 0.0 & 0.0 \\
$\mathrm{Py}$ & 8.29 & 8.81 & 6.21 & 8.99 & 6.04 & 7.46 & 7.32 & 6.67 & 9.26 \\
$\mathrm{Spe}$ & 3.3 & 2.88 & 3.82 & 3.04 & 14.43 & 12.47 & 2.38 & 2.6 & 8.1 \\
$\mathrm{Gro}$ & 9.35 & 16.19 & 20.77 & 2.99 & 7.65 & 13.0 & 11.59 & 19.57 & 3.24 \\
$\mathrm{Alm}$ & 79.07 & 71.85 & 69.2 & 83.94 & 69.74 & 66.86 & 78.71 & 71.16 & 79.41 \\
\hline & & & & & & & & & \\
\hline
\end{tabular}

Legend: $\mathrm{Adr}=$ andradite, $\mathrm{Py}=$ pyrope, $\mathrm{Spe}=$ spessartine, Gro = grossular, $\mathrm{Alm}=$ almandine, $\mathrm{FeO}^{*}$ total iron oxide expressed as $\mathrm{FeO}$.

1. Ca-poor edge of a garnet from the garnet and plagioclase-bearing chlorite-muscovite-quartz schist from the sample Gl-8; 2. Ca-rich rim of a garnet from the same sample; 3 . Core of the same garnet; 4. Rim of a garnet from the garnet-bearing chlorite-muscovite schist from the VH-6 sample (lacking plagioclase); 5 . Core of the same garnet; 6 . Garnet core with chloritoid and chlorite inclusions (Gl-6 sample); 7. Garnet rim from the quartz-tourmaline vein; 8. Core of the same garnet; 9 . Pre-alpine garnet core from the the garnet-bearing, chlorite-muscovite schist.

Jelmagyarázat: $A d r=$ andradit Py = pirop; Spe = szpesszartin; Gro $=$ grosszulár $;$ Alm = alman din; $\mathrm{FeO}{ }^{*}$ - az összes vasat $\mathrm{FeO}$ formájában adtuk meg

1. Ca-szegény gránát szegély a GL-8-as plagioklászt is tartalmazó gránátos klorit-muszkovitpalából; 2. Ca-gazdag gránát szegély ugyanabból a mintából; 3.A „2." gránát magja; 4. Gránát szegély a VH-6-os plagioklászt nem tartalmazó gránátos klorit-muszkovitpalából; 5. A „4." gránát magja; 6. Klorit és kloritoidzárványos gránát magja; 7. Gránát szegélye kvarc-turmalinérböl; 8. A „7" gránát magja; 9. Pre-alpi gránátszegély a gránátos klorit-muszkovitpalából.

Ca-rich garnet core were also measured together with the surrounding garnet. In order to obtain both $\mathrm{P}$ and $\mathrm{T}$, plagioclase-bearing assemblages were the preferred ones. In the respective cases of biotite, free samples of garnet-phengite (GREEN \& HeLlMAN, 1982) and garnet-chlorite (DiCKENSON \& HewITT, 1986), thermometers were used with a garnetmuscovite-plagioclase-quartz geobarometer (HODGES \& CROWLEY 1985). A garnet-biotite geothermometer (FERRY \& SPEAR 1978 calibration with the garnet model of BERMAN 1990) and a garnet-biotite-plagioclase-muscovite geothermobarometer (HODGES \& CROWLEY 1985) were used in the case of biotite-bearing samples.

The three applied thermometers were tested against each other in the case of the plagioclase-free VH-6 sample. As can be seen in Table $V$, the temperature agreement is quite good between the respective calibrations of the three thermometers.
Table IV. Representative biotite, chlorite and chloritoid analyses. biotite and chlorite cation numbers are calculated on the basis of $22 \mathrm{O}$, and chloritoid cation numbers are on the basis of $12 \mathrm{O}$

IV. táblázat. Reprezentatív biotit, klorit és kloritoid elemzések. A biotit és klorit kationszámokat 22, a kloritoidot pedig 12 oxigénre számoltuk

\begin{tabular}{cccccccccc}
\hline & 1 & 2 & 3 & 4 & 5 & 6 & 7 & 8 & 9 \\
$\mathrm{SiO}_{2}$ & 36.93 & 36.9 & 25.65 & 26.24 & 24.77 & 29.08 & 29.33 & 24.76 & 25.03 \\
$\mathrm{Al}_{2} \mathrm{O}_{3}$ & 17.36 & 17.08 & 22.46 & 22.21 & 22.63 & 25.61 & 24.06 & 39.12 & 40.75 \\
$\mathrm{TiO}_{2}$ & 1.28 & 1.47 & b.d. & b.d. & b.d. & b.d. & b.d. & b.d. & b.d. \\
$\mathrm{Fe}^{*}$ & 20.91 & 20.01 & 27.94 & 26.06 & 28.35 & 4.38 & 6.8 & 24.47 & 23.0 \\
$\mathrm{MgO}$ & 9.75 & 10.44 & 13.36 & 15.48 & 11.0 & 29.04 & 28.58 & 3.07 & 3.7 \\
$\mathrm{MnO}$ & 0.0 & 0.0 & b.d. & b.d. & 0.1 & b.d. & b.d. & 0.3 & 0.05 \\
$\mathrm{~K} 0$ & 8.56 & 8.54 & n.a. & n.a. & n.a. & n.a. & n.a. & n.a. & n.a. \\
$\mathrm{Na}{ }_{2} \mathrm{O}$ & 0.34 & 0.39 & n.a. & n.a. & n.a. & n.a. & n.a. & n.a. & n.a. \\
$\mathrm{Sum}$ & 95.13 & 94.83 & 89.41 & 89.99 & 86.85 & 88.11 & 88.77 & 91.72 & 92.53 \\
$\mathrm{Si}$ & 5.63 & 5.63 & 4.2 & 4.23 & 4.2 & 4.25 & 4.32 & 2.06 & 2.05 \\
$\mathrm{Al}$ & 3.12 & 3.07 & 4.34 & 4.22 & 4.52 & 4.42 & 4.17 & 3.84 & 3.92 \\
$\mathrm{Ti}$ & 0.15 & 0.17 & 0.0 & 0.0 & 0.0 & 0.0 & 0.0 & 0.0 & 0.0 \\
$\mathrm{Fe} 2$ & 2.67 & 2.55 & 3.83 & 3.51 & 4.02 & 0.54 & 0.84 & 1.71 & 1.57 \\
$\mathrm{Mg}$ & 2.22 & 2.37 & 3.26 & 3.72 & 2.78 & 6.33 & 6.27 & 0.38 & 0.45 \\
$\mathrm{Mn}$ & 0.0 & 0.0 & 0.0 & 0.0 & 0.01 & 0.0 & 0.0 & 0.02 & 0.0 \\
$\mathrm{~K}$ & 1.67 & 1.66 & 0.0 & 0.0 & 0.0 & 0.0 & 0.0 & 0.0 & 0.0 \\
$\mathrm{Na}$ & 0.1 & 0.12 & 0.0 & 0.0 & 0.0 & 0.0 & 0.0 & 0.0 & 0.0 \\
$\mathrm{Sumcat}$ & 15.55 & 15.56 & 15.63 & 15.67 & 15.54 & 15.54 & 15.6 & 8.01 & 7.99 \\
\hline
\end{tabular}

Legend: b.d. = below detection, n.a. $=$ not analysed, $\mathrm{FeO}^{*}$ total iron oxide expressed as $\mathrm{FeO}$. 1. Biotite from the garnet-bearing, chlorite-muscovite schist; 2 . Biotite inclusion in a high Ca garnet zone from garnet-bearing, chlorite-muscovite schist; 3 . Chlorite from the same sample. 4. Chlorite inclusion in garnet associated with chloritoid; 5. Chlorite from a quartz-tourmaline vein; 6. Chlorite from the paragonite-bearing leucophyllite; 7. Chlorite from the leucophyllite; 8 . Chloritoid inclusion in garnet core associated with chlorite; 9 . Chloritoid in a paragonite-muscovite-albite-biotite aggregate from the garnet-bearing, chlorite-muscovite schist.

Jelmagyarázat: b.d. $=$ kimutatási határ alatt; $n$.a. $=$ nem elemzett $; \mathrm{FeO}$ - az összes vasat $\mathrm{FeO}$ formájában adtuk meg.

1. Biotit a gránátos klorit-muszkovitpalából; Biotit zárvány a nagy Ca-tartalmú gránát zónából; 3. Klorit, ugyanabból a mintából; 4. Klorit zárvány a gránát magjából, kloritoiddal társulva; 5. Klorit kvarc-turmalinérböl; 6. Klorit paragonitos leukofillitböl; 7. Klorit leukofillitböl; 8. Kloritoidzárvány gránát magjából klorittal társulva; 9. Kloritoid muszkovitparagonit-albit csomóból.

Some of the garnets contain chlorite and chloritoid inclusions within this Mn-rich core. The garnet-chlorite thermometry of the Gl-6 sample gives temperatures of 456 , 464 and $472{ }^{\circ} \mathrm{C}$ at pressures of 700, 1000 and $1300 \mathrm{MPa}$, respectively (Table $V$ ) for the garnet core with chloritoid and chlorite inclusions. Such garnets with chloritoid inclusions are described by WANG \& SPEAR (1991) from a Barrovianmetapelitic sequence. They suggest a reaction took place, in which chloritoid, biotite and quartz were broken down to form garnet, muscovite and chlorite. This reaction would explain the predominance of chlorite and muscovite over biotite in the samples.

Garnet-biotite thermometry carried out on the biotite inclusions and the high-Ca garnet zone gives $583-591^{\circ} \mathrm{C}$ at $700 \mathrm{MPa}, 597-605^{\circ} \mathrm{C}$ at $1000 \mathrm{MPa}$, and $610-619^{\circ} \mathrm{C}$ at 1300 $\operatorname{MPa}($ Table V).

Temperatures obtained from garnet rims vary between 
Table V. Summary of geothermo-barometric calculations on different samples

V. táblázat. A geotermo-barometriai számítások összefoglalása

\begin{tabular}{|c|c|c|c|c|c|}
\hline Sample & $\begin{array}{l}\text { Gar-bi thermometer } \\
\text { with gar-bi-pl-mu } \\
\text { barometer }\end{array}$ & $\begin{array}{l}\text { Gar-phe thermometer } \\
\text { with gar-mu-pl-q } \\
\text { barometer }\end{array}$ & $\begin{array}{l}\text { Gar-chl thermometer with } \\
\text { gar-mu-pl-q barometer }\end{array}$ & Gar-bi thermometer & Gar-chl thermometer \\
\hline Gl-6 & & $\begin{array}{c}600-630^{\circ} \mathrm{C} \\
\text { and } 1040-1190 \mathrm{MPa} \\
\end{array}$ & $\begin{array}{l}535-605{ }^{\circ} \mathrm{C} \text { and } \\
840-1120 \mathrm{MPa}\end{array}$ & & \\
\hline $\begin{array}{l}\text { Gl- } 6 \text { chlorite inchsion } \\
\text { in high-Mn garnet } \\
\text { core }\end{array}$ & & & & & $\begin{array}{l}448^{\circ} \mathrm{C} \text { at } 400 \mathrm{MPa}, \\
456^{\circ} \mathrm{C} \text { at } 700 \mathrm{MPa}, \\
464^{\circ} \mathrm{C} \text { at } 1000 \mathrm{MPa}, \\
472{ }^{\circ} \mathrm{C} \text { at } 1300 \mathrm{MPa}\end{array}$ \\
\hline Gl-5 & & $\begin{array}{l}560-620^{\circ} \mathrm{C} \text { and } \\
850-1130 \mathrm{MPa} \\
\end{array}$ & $\begin{array}{l}595-620{ }^{\circ} \mathrm{C} \text { and } \\
970-1120 \mathrm{MPa} \\
\end{array}$ & & \\
\hline $\begin{array}{l}\text { Gl- } 5 \text { biotite inclusion } \\
\text { in high-Ca gar core }\end{array}$ & & & & $\begin{array}{l}569-577^{\circ} \mathrm{C} \text { at } 400 \mathrm{MPa}, \\
583-591{ }^{\circ} \mathrm{C} \text { at } 700 \mathrm{MPa} \text {, } \\
597-605{ }^{\circ} \mathrm{C} \text { at } 1000 \mathrm{MPa} \text {, } \\
610-619^{\circ} \mathrm{C} \text { at } 1300 \mathrm{MPa}\end{array}$ & \\
\hline $\begin{array}{l}\text { Gl-8 (high-Ca garnet } \\
\text { rim) }\end{array}$ & $\begin{array}{c}540-605^{\circ} \mathrm{C} \\
\text { and } 930-1220 \mathrm{MPa}\end{array}$ & & & & \\
\hline $\begin{array}{l}\text { Gl-8 (lower Ca garnet } \\
\text { rim) }\end{array}$ & $\begin{array}{l}570-5900^{\circ} \mathrm{C} \text { and } \\
840-940 \mathrm{MPa}\end{array}$ & & & & \\
\hline $\mathrm{VH}-6$ & & & $\begin{array}{c}552-577^{\circ} \mathrm{C} \text { at } 400 \mathrm{MPa} \text {, } \\
567-593^{\circ} \mathrm{C} \text { at } 700 \mathrm{MPa}, \\
583-608^{\circ} \mathrm{C} \text { at } 1000 \mathrm{MPa} \text {, } \\
599-621^{\circ} \mathrm{C} \text { at } 1300 \mathrm{MPa} \\
\text { (gar-phe thermometer } \\
\text { only!) }\end{array}$ & $\begin{array}{l}547-569^{\circ} \mathrm{C} \text { at } 400 \mathrm{MPa}, \\
559-582^{\circ} \mathrm{C} \text { at } 700 \mathrm{MPa}, \\
572-594^{\circ} \mathrm{C} \text { at } 1000 \mathrm{MPa}, \\
585-606{ }^{\circ} \mathrm{C} \text { at } 1300 \mathrm{MPa}\end{array}$ & $\begin{array}{l}544-583{ }^{\circ} \mathrm{C} \text { at } 400 \mathrm{MPa} \text {, } \\
553-592^{\circ} \mathrm{C} \text { at } 700 \mathrm{MPa} \text {, } \\
562-602{ }^{\circ} \mathrm{C} \text { at } 1000 \mathrm{MPa} \text {, } \\
571-612{ }^{\circ} \mathrm{C} \text { at } 1300 \mathrm{MPa}\end{array}$ \\
\hline$q$-tourmaline vein & & $\begin{array}{l}560-610^{\circ} \mathrm{C} \text { and } \\
950-1230 \mathrm{MPa}\end{array}$ & & & \\
\hline
\end{tabular}

540 and $630{ }^{\circ} \mathrm{C}$. The pressures show greater variations (between 840 and $1230 \mathrm{MPa}$ ), depending on the Ca-content of the garnet rim and the contacting plagioclase. These P-T data are in good agreement with the data of DRAGANITS (1998) with reference to the Austrian part of the Sopron micaschist $\left(550 \pm 30{ }^{\circ} \mathrm{C}, 0.95 \pm 0.15 \mathrm{GPa}\right)$.

A combination of garnet-phengite thermometry with garnet-muscovite-plagioclase-quartz barometry in quartztourmaline veins produced results of $560-610^{\circ} \mathrm{C}$ and 950 $1230 \mathrm{MPa}$. The summary of the geothermo-barometric results are given in Table $V$.

\section{Fluid inclusions}

All fluid inclusions were found in quartz veins and segregations of the Sopron micaschist, and in the quartz veins with florencite-type mineralisation in the leucophyllite. The quartz veins are parallel with the schistosity or, in rare cases, cross-cut it. The observed inclusions are all in secondary trails and these cross-cut the grain boundaries. Some of the trails can be followed across the entire thin section and they contain a lot of decrepitated inclusions. The latter are mostly dark and have a decrepitation halo of small fluid inclusions around the former inclusion. Some of the inclusion trails cross-cut thin tourmaline-bearing veinlets within the quartz vein; this indicates that these fluids postdate the formation of the quartz-tourmaline veins.

Three types of fluid inclusions can be observed in the quartz veins:

Type 1. Monophase $\mathrm{CO}_{2}$ inclusions are found in the quartz veins of the micaschist, and in the quartz veins with florencite mineralisation in the leucophyllites. The size of the inclusions does not exceed $10-15 \mu \mathrm{m}$. The shape of the $\mathrm{CO}_{2}$ inclusions can be of a more or less rounded, negative crystal-like form, or irregular. The $\mathrm{CO}_{2}$ inclusions were exclusively found in association with multiphase hypersaline inclusions, with or without $\mathrm{CO}_{2}$ in the secondary inclusion trails. Most of the inclusions contain a minor aqueous phase. Dark, amoeboid, decrepitated $\mathrm{CO}_{2}$ inclusions were found very frequently. Melting points close to $-56.6{ }^{\circ} \mathrm{C}$ (between -56.7 and $-57.4^{\circ} \mathrm{C}$, see Figure $6 a$ ) show that the inclusions contain almost pure $\mathrm{CO}_{2}$. The homogenisation temperatures range from -8.0 to $+15.8^{\circ} \mathrm{C}$ with a peak around $-5^{\circ} \mathrm{C}$ (Figure $6 b$ ).

Type 2. Multiphase, hypersaline aqueous inclusions with one or more solid daughter minerals. This type of inclusion is mainly found in the quartz veins associated with florencite-type mineralisation in leucophyllites; it was also observed in the matrix quartz grains of the Sopron micaschist, but these latter grains were too small to measure.

The shape of the inclusions is usually irregular or, in rare cases, tubular. The size of the inclusions extends up to 30$35 \mu \mathrm{m}$. Some of the inclusions contain a $\mathrm{CO}_{2}$ bubble. When $\mathrm{CO}_{2}$ is present, in most cases the aqueous phase $/ \mathrm{CO}_{2}$ ratio is highly variable; this indicates immiscibility between the two fluids. Usually there is only one soluble daughter mineral (S1; halite cube), but other unidentified insoluble solid daughter minerals may also be present. Decrepitation was observed in several cases, especially with respect to bigger inclusions.

The inclusions of this type have complex low temperature behaviour. During the cooling down of the inclusions, the change in the first phase is represented by the appearance of a solid soluble daughter mineral (S2), this usually occurs between $-5{ }^{\circ} \mathrm{C}$ and $-30{ }^{\circ} \mathrm{C}$. The change 

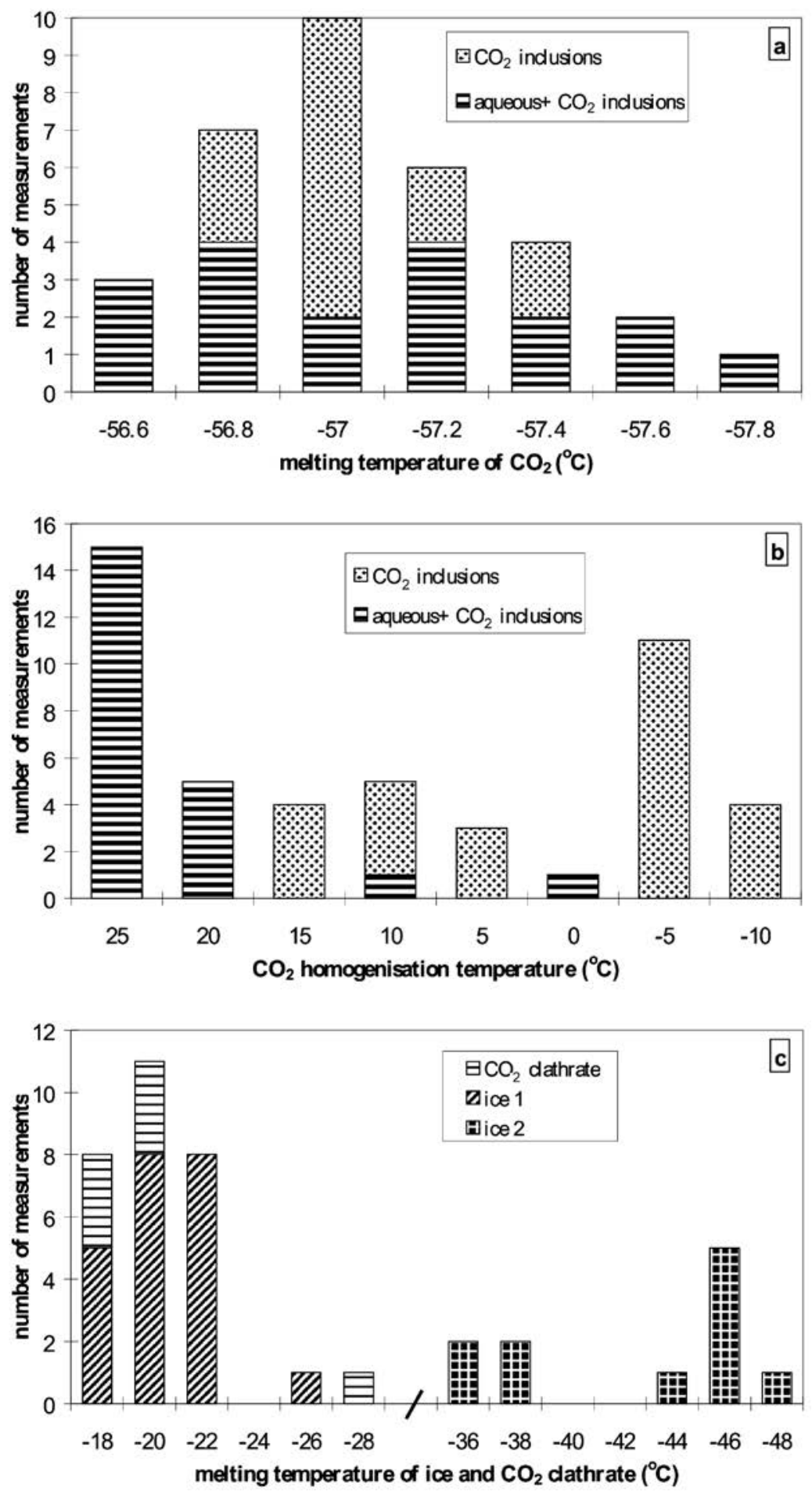

Figure 6. a) Melting temperature distribution of $\mathrm{CO}_{2}$ in the $\mathrm{CO}_{2}$ and $\mathrm{CO}_{2}$-bearing hypersaline aqueous inclusions. b) Homogenisation temperatures of $\mathrm{CO}_{2}$ in the $\mathrm{CO}_{2}$ and $\mathrm{CO}_{2}$-bearing hypersaline aqueous inclusions. c) Ice melting temperatures in the hypersaline aqueous inclusions with or without a visible $\mathrm{CO}_{2}$ phase. The diagram also shows the $\mathrm{CO}_{2}$ clathrate melting temperatures in the hypersaline aqueous inclusions with $\mathrm{CO}_{2}$

Legend: ice 1 - ice melting temperatures in the presence of hydrohalite; ice 2 - ice melting temperatures in the absence of hydrohalite; $\mathrm{CO}_{2}$ clathrate - $\mathrm{CO}_{2}$ clathrate melting temperatures

6. ábra. a) $\mathrm{A} \mathrm{CO}_{2}$-és a $\mathrm{CO}_{2}$-hiperszalin vizes zárványokban mért $\mathrm{CO}_{2}$ olvadási hömérsékletek. b) $\mathrm{A} \mathrm{CO}_{2}$ és a $\mathrm{CO}_{2}$-hiperszalin vizes zárványokban mért $\mathrm{CO}_{2}$ homogenizációs hömérsékletek. c) a hiperszalin vizes zárványokban $\left( \pm \mathrm{CO}_{2}\right)$ mért jég olvadási hömérsékletek. A diagramba felvittük a $\mathrm{CO}_{2}$ klatrát olvadási hömérsékletét is, melyet a $\mathrm{CO}_{2}$-hiperszalin vizes zárványokban mértünk.

Jelmagyarázat: ice 1 - jég olvadási hömérséklet hidrohalit jelenlétében; ice 2 - jég olvadási hömérséklet hidrohalit nélkül; $\mathrm{CO}_{2}$ clathrate - $\mathrm{CO}_{2}$ klatrát olvadás. in the next phase is represented by the beginning of the formation of hydrohalite (H1) at the edge of the halite cube. The aqueous liquid in the inclusions froze below $-70{ }^{\circ} \mathrm{C}$, and the $\mathrm{CO}_{2}$ froze at about $-100{ }^{\circ} \mathrm{C}$. After the total freezing of the aqueous phase, the system was warmed slowly until the last ice crystal remained. On warming, the amount of hydrohalite increased at the expense of the halite, but in most cases the transformation of halite to hydrohalite was not complete. The system was cooled down again until the last ice crystal remained at $-130{ }^{\circ} \mathrm{C}$. In most cases freezing was not observed. On warming up from $-130{ }^{\circ} \mathrm{C}$, several small, bright, rounded or acicular crystals appeared at about $-85{ }^{\circ} \mathrm{C}$. These small crystals were growing during the slow warming at the expense of the aqueous phase; furthermore, they seemed to occupy the inclusion cavity, thus distorting the bubble. A similar observation was published by DAVIS et al. (1990) in the $\mathrm{NaCl}-\mathrm{CaCl}_{2}-$ $\mathrm{H}_{2} \mathrm{O}$ and $\mathrm{NaCl}-\mathrm{MgCl}_{2}-\mathrm{H}_{2} \mathrm{O}$ systems, with metastable eutectic points. During heating, they observed small crystals growing from -80 to $-50{ }^{\circ} \mathrm{C}$; they interpreted this as the formation and recrystallisation of a salt hydrate phase. Melting of this salt hydrate phase (H2: $\mathrm{CaCl}_{2}$-hydrate or $\mathrm{FeCl}_{2}$-hydrate?) began at about $-67^{\circ} \mathrm{C}$ and was completed between -58.2 and $-47.3{ }^{\circ} \mathrm{C}$. Melting of the solid $\mathrm{CO}_{2}$ phase in the bubble occurred between -56.6 and $-57.8^{\circ} \mathrm{C}$ (Figure $6 a)$. The first melting of the ice crystal was observed at about $-35{ }^{\circ} \mathrm{C}$ and the final melting of the ice occurred between -18.7 and $-26.4{ }^{\circ} \mathrm{C}$ (ice 1 on Figure $6 c$ ). The disappearance of the $\mathrm{CO}_{2}$-hydrate occurred between -17.8 and $-19.3{ }^{\circ} \mathrm{C}$ (Figure $\left.6 c\right)$. The transformation of the hydrohalite back to halite occurred metastably, between +7.8 and $+12.5^{\circ} \mathrm{C}$. This was followed by the homogenisation of the $\mathrm{CO}_{2}\left(+16.6-+24.1^{\circ} \mathrm{C}\right.$; Figure 6b).

Further heating of the inclusions caused the $\mathrm{S} 2$ solid phase to dissolve, between +23.7 and $+89{ }^{\circ} \mathrm{C}$ (Figure $7 a$ ). Dissolution of the S1 solid phase occurred between 164 and 298 ${ }^{\circ} \mathrm{C}$ (Figure 7a). Most of the inclusions did not homogenise but decrepitated prior to homogenisation between 265 and $400{ }^{\circ} \mathrm{C}$. However, in some cases final homogenisation of the bubble could be observed between 271 and $296{ }^{\circ} \mathrm{C}$ (Figure $7 b$ ).

There were several cases when the halite did not react with the aqueous phase to form 

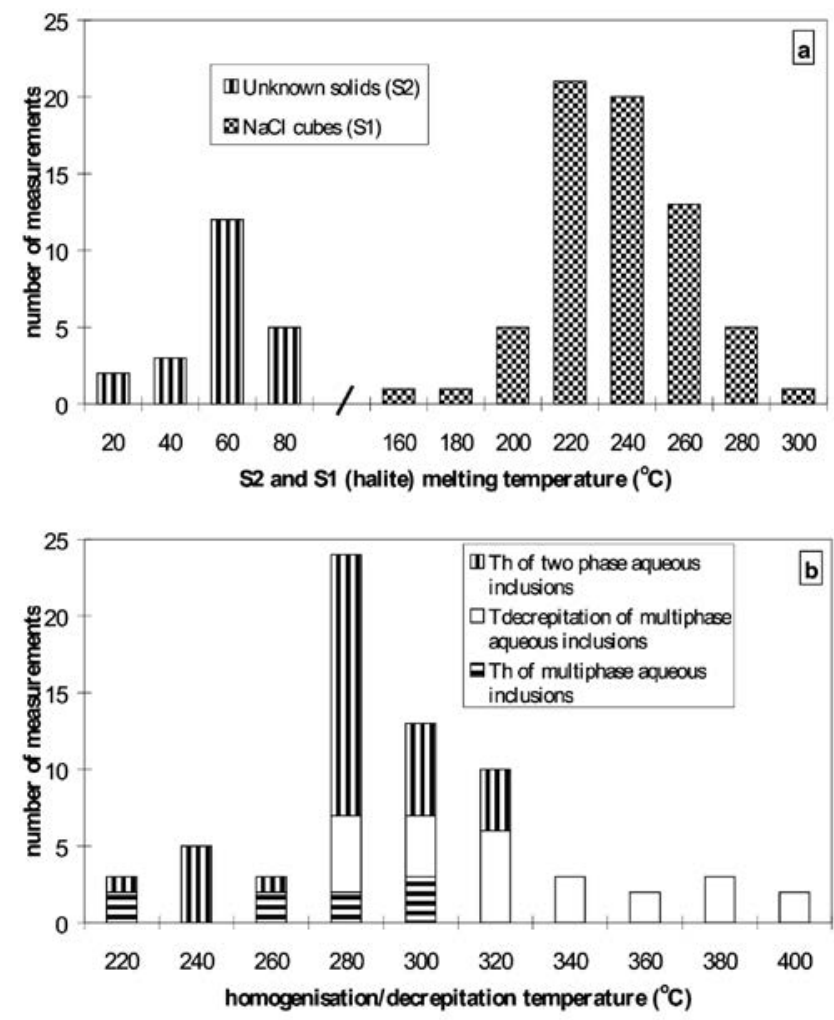

Figure 7. a) Solid daughter phase (S2) and halite (S1) dissolution temperatures in the hypersaline aqueous inclusions, with or without a visible $\mathrm{CO}_{2}$ phase. b) Homogenisation and decrepitation temperatures of multiphase aqueous inclusions and homogenisation temperatures of two phase aqueous inclusions 7. ábra. a) Szilárd (ismeretlen) fázis (S2) és kösó (S1) oldódási hömérsékletek a hiperszalin vizes zárványokban $\left( \pm \mathrm{CO}_{2}\right)$; b) Homogenizációs és dekrepitációs hömérsékletek a többfázisú vizes zárványokban és homogenizációs hömérsékletek a kétfázisú vizes zárványokban

hydrohalite. In such cases the ice-melting temperature occurred at lower temperatures: between -35.8 and $-47.9^{\circ} \mathrm{C}$ (ice 2 on Figure $6 c$ ). This phenomenon is similar to that observed in the $\mathrm{NaCl}-\mathrm{CaCl}_{2}-\mathrm{H}_{2} \mathrm{O}$ system, when hydrohalite is absent. In this case the ice melting temperatures are much lower.

Type 3. Two phase (liquid+vapour) aqueous inclusions. This inclusion type occurs exclusively in the quartz veins of the Sopron micaschist. This type was found along secondary inclusion trails cross-cutting several grain boundaries. The shape of this inclusion type is usually irregular, in rare cases rounded, and negative crystal-like inclusions can also occur. The size of the inclusions usually do not exceed $15-20 \mu \mathrm{m}$. Two-phase aqueous inclusions are usually not associated with inclusion trails of $\mathrm{CO}_{2}$ and hypersaline aqueous inclusions. However, one of the quartz veins contains (i) cracks with oriented tourmaline laths, (ii) healed fractures with two-phase aqueous fluid inclusions and (iii) multiphase hypersaline aqueous fluid inclusions $\pm \mathrm{CO}_{2}$. The temporal relationship between the three fluid events can be traced from textural observations. The tourmaline-bearing cracks are cut by both the two-phase and multiphase inclusion trails; this implies that these trails postdate the tourmalinisation. The temporal relationship between the two latter fluid generations is less certain. The inclusion trails of the two-phase aqueous fluid inclusion type sometimes cross-cut the ones with the multiphase aqueous inclusions. The fractures along which the two phase aqueous inclusions were sealed seem to be more pronounced or less mature (OLSEN 1987) than the ones along which the multiphase aqueous inclusions were sealed. These textural observations imply that the two-phase aqueous inclusions are younger than the multiphase aqueous inclusions.

During the cooling down of the two-phase aqueous inclusions, the inclusion content freezes below $-70^{\circ} \mathrm{C}$ and a brownish solid is formed. Slow heating resulted in the brightening of the frozen inclusion, and the first melting was observed between -49 and $-55^{\circ} \mathrm{C}$. Further heating gave rise to a gradual melting of ice. The heating was continued until the last crystal of hydrohalite remained. At this point the temperature was lowered again and this resulted in the growth of the hydrohalite and freezing. Repeated heating until the last ice crystal coexisted with the hydrohalite was followed by the next cooling cycle; the latter produced an idiomorphic hydrohalite and a big ice crystal. Slow heating of the inclusion caused the frozen liquid to melt, and the rounding of the edge of the ice crystal between -51 and $-53{ }^{\circ} \mathrm{C}$; this is close to the eutectic of the $\mathrm{NaCl}-\mathrm{CaCl}_{2}-\mathrm{H}_{2} \mathrm{O}$ system. Sometimes the disappearance of small bright crystals (probably antarcticite) was observed. Continued heating resulted in the gradual melting of ice, while the composition of the liquid shifted along the cotectic line. This caused the separation of the hydrohalite and ice fields (Figure 8) until the melting of the ice between -23.2 and $-28.4{ }^{\circ} \mathrm{C}$. After the melting of the ice, the fluid composition moved towards the hydrohalite point on the $\mathrm{H}_{2} \mathrm{O}-\mathrm{NaCl}$ intersection of the $\mathrm{NaCl}-\mathrm{CaCl}_{2}-\mathrm{H}_{2} \mathrm{O}$ triangle (Figure 8); until hydrohalite melted between 0 and $-14.7{ }^{\circ} \mathrm{C}$. All inclusions of this type behaved in this way during low

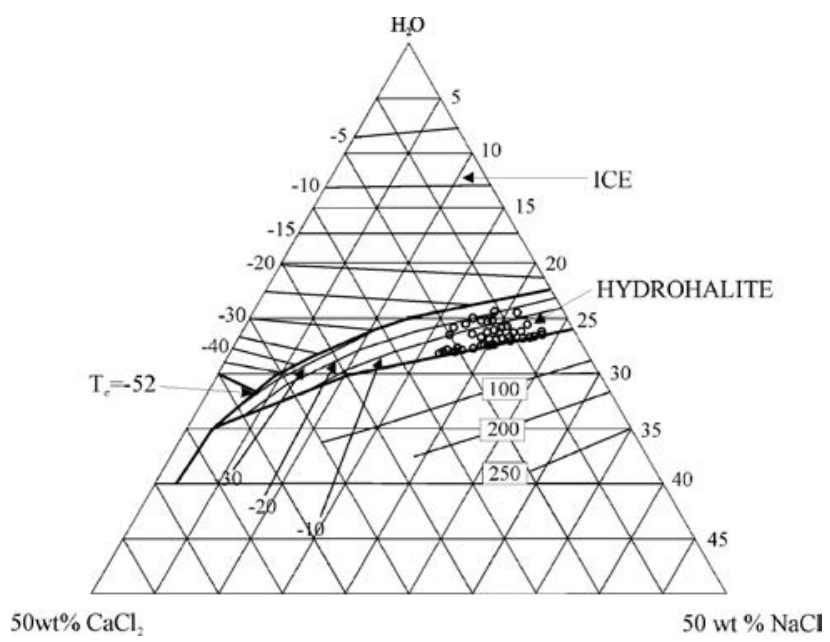

Figure 8. $\mathrm{NaCl} 50-\mathrm{CaCl}_{2} 50-\mathrm{H}_{2} \mathrm{O}$ phase diagram showing salinities of two phase aqueous inclusions (after YANATIEVA 1949, VANKO et al. 1988 and OAKES et al. 1990)

8. ábra. A kétfázisú vizes zárványok sótartalma a $\mathrm{NaCl} 50-\mathrm{CaCl}_{2} 50-\mathrm{H}_{2} \mathrm{O}$ fázisdiagramon (YANATIEVA 1949, VANKO et al. 1988 és OAKES et al. 1990 nyomán) 
temperature experiments. The plotting of the data into the $\mathrm{NaCl}-\mathrm{CaCl}_{2}-\mathrm{H}_{2} \mathrm{O}$ ternary diagram (Figure 8 ) indicated a total salinity between 25 and $28.5 \%$. The $\mathrm{NaCl} / \mathrm{CaCl}_{2}$ ratio is between 6.4 and 1.4, and the inclusions homogenise between 229.6 and $322{ }^{\circ} \mathrm{C}$ with a mode around $280{ }^{\circ} \mathrm{C}$ (Figure $7 b$ ).

\section{Solution chemistry of the hypersaline aqueous fluid inclusions}

The complicated low temperature phase changes and the low first melting temperatures indicate that the abovementioned $\mathrm{NaCl}-\mathrm{CaCl}_{2}-\mathrm{H}_{2} \mathrm{O}$ solution chemistry can be considered as no more than a first approximation. Therefore, in order to give a more precise solution chemistry, semiquantitative EDS analyses were made both on precipitated salts (from inclusions decrepitated by heating up to $600{ }^{\circ} \mathrm{C}$ ), and on crushed pieces of the quartz veins containing hypersaline brines. The analyses indicate a complex solution chemistry, as inferred from the low temperature phase changes. In most cases higher amounts of $\mathrm{Na}, \mathrm{Al}, \mathrm{K}, \mathrm{Ca}, \mathrm{Cl}$ and $\mathrm{S}$ were found. $\mathrm{Mg}, \mathrm{Fe}$ and $\mathrm{P}$ were detected in almost all of the examined inclusion cavities, usually in small amounts (Figures 9A and 9B). In some of the inclusions Fe has been enriched. $\mathrm{Mn}$ is the major compound in two inclusions
(Figure 9B), whereas $\mathrm{Zn}$ and $\mathrm{Ti}$ were found only occasionally. Muscovite and calcite were also observed as solids in the inclusion cavity. One of the inclusions contained a REE+Th-bearing phase, along with different kinds of salts (Figure 9c). The REE+Th-bearing phase contained high amounts of $\mathrm{Fe}, \mathrm{Al}, \mathrm{K} \mathrm{Ca}$, $\mathrm{La}$ and $\mathrm{Ce}$, along with $\mathrm{Na}, \mathrm{Mg}, \mathrm{P}$, $\mathrm{S}, \mathrm{Cl}, \mathrm{Th}$, and Nd. Several small salt crystals were also determined around the REE+Th-bearing phase; the latter contained high amounts of $\mathrm{Na}, \mathrm{Al}, \mathrm{Cl}, \mathrm{K}$, and $\mathrm{Ca}$ alongside $\mathrm{Mg}, \mathrm{P}, \mathrm{S}, \mathrm{Ti}, \mathrm{Mn}$ and Fe.

\section{Discussion}

On the basis of fluid inclusion textures and data, as well as textural observations and mineral chemistry data, four main fluid migration events can be identified in the studied samples.

1. High-pressure veining and tourmalinisation in the host rock.

Geothermo-barometry demonstrated temperatures between $560-610^{\circ} \mathrm{C}$ and pressures between $950-1230 \mathrm{MPa}$ (Figure 10). Intergrowths of garnet and tourmaline show that the mineral assemblage used for thermo-barometry and the tourmaline itself crystallized contemporaneously. According to other P-T data from the area (TÖRÖK 1998, 2003),
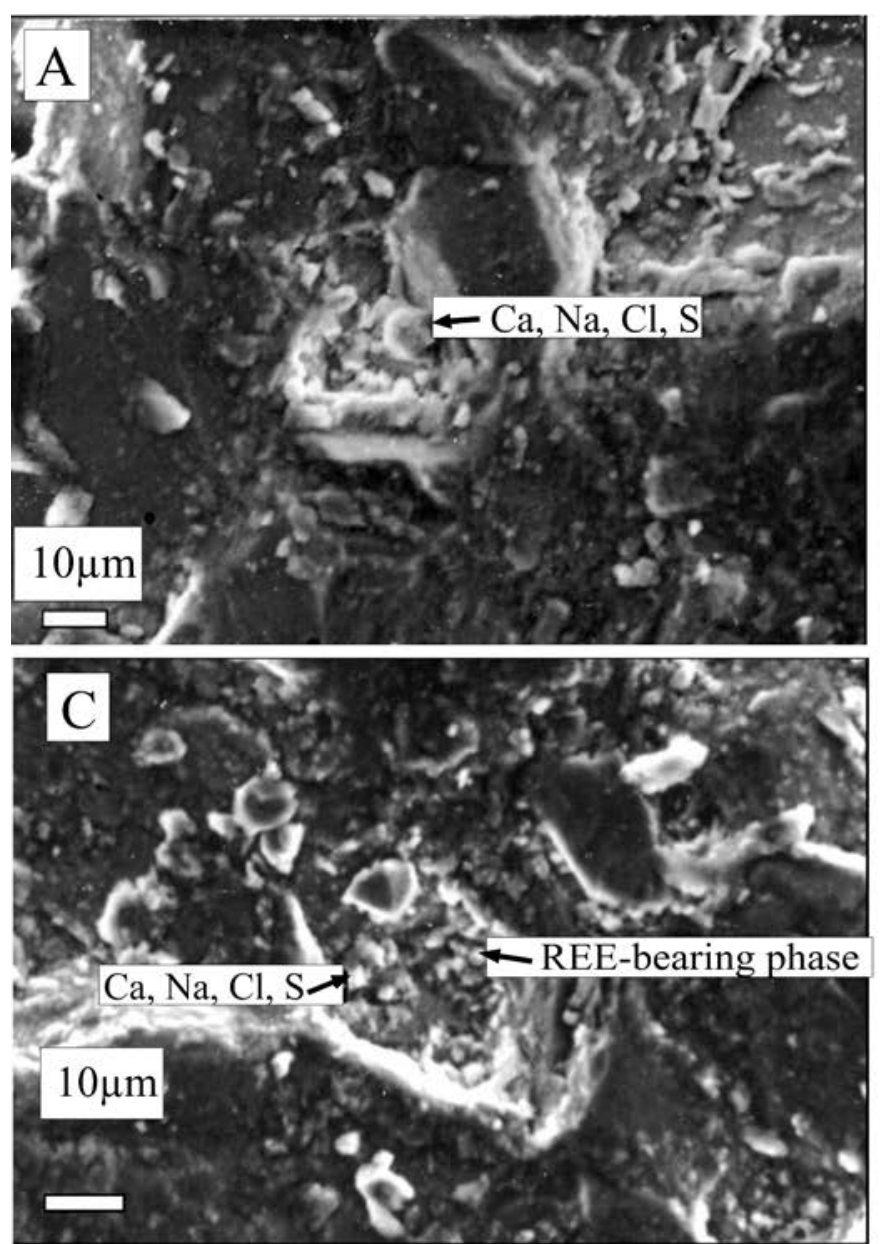

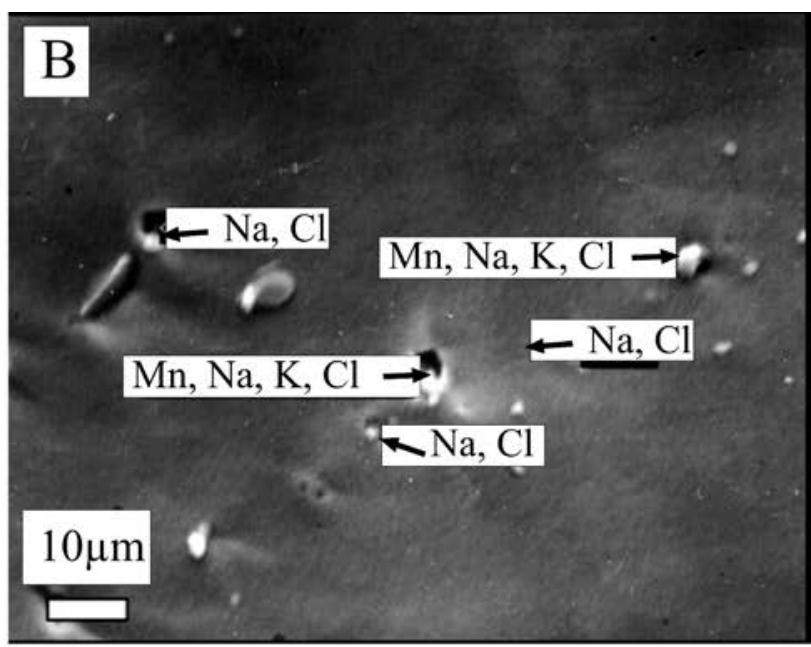

Figure 9. SEM pictures of opened inclusions: A) From a quartz vein of the garnet-bearing chlorite-muscovite schist. The biggest solid phase contains mainly $\mathrm{Ca}, \mathrm{Na}, \mathrm{Cl}$ and $\mathrm{S}$. Further detected components are: $\mathrm{Al}, \mathrm{Mg}, \mathrm{K}, \mathrm{Fe}, \mathrm{Mn}$, $\mathrm{Zn}$, Ti and P; B) From an inclusion trail in a quartz from the leucophyllite. The main components are $\mathrm{Na}, \mathrm{K}, \mathrm{Cl}$ and $\mathrm{Mn}$. Minor components are: $\mathrm{Mg}, \mathrm{Al}, \mathrm{P}$ and $\mathrm{S} ; \mathrm{C}$ ) In a quartz vein of the leucophyllite. The inclusion contains a REE+Thbearing phase and several small salt crystals. The REE+Th-bearing phase is rich in $\mathrm{Fe}, \mathrm{Al}, \mathrm{K} \mathrm{Ca} \mathrm{La}$ and $\mathrm{Ce}$. Other detected elements include: $\mathrm{Na}, \mathrm{Mg}, \mathrm{P}, \mathrm{S}, \mathrm{Cl}$, $\mathrm{Th}$, and $\mathrm{Nd}$. The small salt crystals contain high amounts of $\mathrm{Na}, \mathrm{Al}, \mathrm{Cl}, \mathrm{K}, \mathrm{Ca}$, and lower amounts of $\mathrm{Mg}, \mathrm{P}, \mathrm{S}, \mathrm{Ti}, \mathrm{Mn}$ and $\mathrm{Fe}$

9. ábra. A felnvitott zárványokról készült scanning elektronmikroszkópos felvételek. A) Kvarcér a gránátos klorit-muszkovitpalából. A legnagyobb szilárd fázisban föleg $\mathrm{Ca}, \mathrm{Na}, \mathrm{Cl}$, S detektálható és kisebb mennyiségben $\mathrm{Al}, \mathrm{Mg}, \mathrm{K}, \mathrm{Fe}, \mathrm{Mn}, \mathrm{Zn}$, Ti valamint $P$. B) Zárványsor leukofillitben levö kvarcban, amelyben föleg $\mathrm{Na}, \mathrm{K}, \mathrm{Cl}$ és Mn,ezen felül kisebb mennyiségben $\mathrm{Mg}, \mathrm{Al}, \mathrm{P}, \mathrm{S}$ található. C) Zárvány kvarc érböl, leukofillitben. A zárvány RFF+Th-gazdag fázist és több kisebb só szemesét tartalmaz. Az elöbbiben nagvobb mennyiségü Fe, $\mathrm{Al}, \mathrm{K}, \mathrm{Ca} \mathrm{La}$ és Ce, valamint kevés $\mathrm{Na}, \mathrm{Mg}, \mathrm{P}, \mathrm{S}, \mathrm{Cl}$, Thés Nd volt kimutatható. Az utóbbiakban több $\mathrm{Na}, \mathrm{Al}, \mathrm{Cl}$ K, Ca mellett kevesebb Mg, P, S, Ti, Mn és Fe volt detektálható 


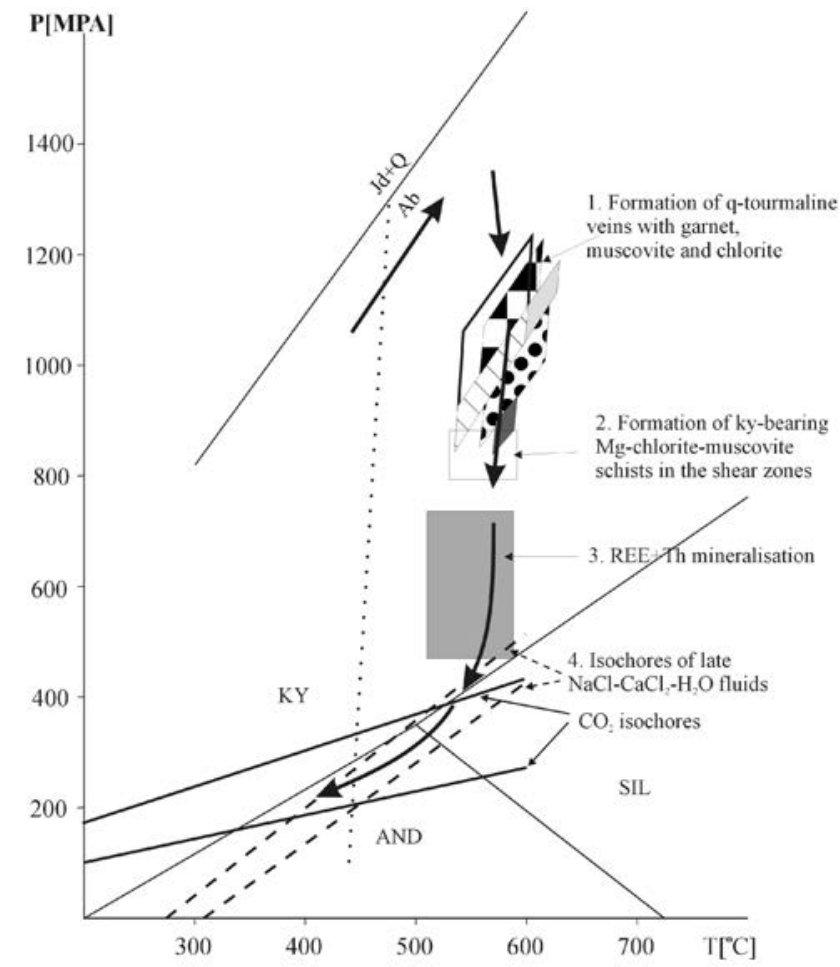

Figure 10. Summary of geothermo-barometric data and fluid migration from the present study and P-T data of TöRöK (1998). The dotted line represents the results of garnet-chlorite thermometry (DICKENSON \& HEWITT 1986) of the chlorite inclusion in association with chloritoid in the garnet core. The boxes refer to P-T data obtained from several samples

10. ábra. A Geotermo-barometriai adatok és fluidummigrációs események összefoglalása, kiegészítve TöRöK (1998) P-T adataival. A pontozott vonal a gránátklorit termometria eredményét mutatja (DICKENSON \& HEWITT 1986 alapján), melyet a gránát magjában levő klorit-kloritoid-együttesben mértünk. A különbözó mintázatú területek különbözö minták méréseiböl származó P-T értékeket foglalnak magukba

the quartz-tourmaline veins formed just after the pressure peak of the Alpine metamorphism. The textural observations listed below show that tourmalinisation preceded the REE-phosphate mineralisation:

a) Allanite, filling the spaces between tourmaline grains in a quartz-tourmaline vein in Füzes-árok (Figure 2E),

b) Idioblastic, undeformed apatites, growing in the vicinity of highly-deformed tourmalines in the same quartz tourmaline vein,

c) Textural observations of cross-cutting fluid inclusion plains, as described in the "Fluid inclusions" section.

Fluids which caused the precipitation of tourmalinequartz veins mainly entered the fractures, and also interacted with some parts of the Sopron micaschist. This is shown by the crystallisation of tourmalines in the micaschist itself. Similar garnet (Figure 5), muscovite (Figure 3) and chlorite compositions in tourmaline-quartz veins and in the Sopron micaschist imply that the host rock may have reached equilibrium with this type of fluid. Furthermore, this equilibrium implies that the fluids may have originated from this rock sequence: most probably from dehydration reactions which dissolved tourmaline from deeper levels and redeposited it at higher crustal levels. SPRÁNITZ et al.
(2018) described several tourmaline mineralisations in the area: among them, the formation of an Fe-rich tourmaline generation in the tourmalinites found in the micaschist close to the peak of the HP metamorphism. The tourmalinisation described here is most probably identical with this generation.

2. Mg metasomatism and leucophyllite formation in the shear zones.

The formation of leucophyllites have been attributed to highly saline but undersaturated complex aqueous fluids (ProchaskA et al. 1997; TÖRÖK 2001). P-T conditions were between $700-1050 \mathrm{MPa}$ and $450-600^{\circ} \mathrm{C}$. The differences in the mineral chemistry and mineral composition of the leucophyllites and host schists show that this fluid was not in equilibrium with the host rock; furthermore, it percolated mainly along shear zones thus causing metasomatism (KISHÁZI \& IVANCSICS 1985, DEMÉNY et al. 1997, TÖRÖK 2001)

Opinions on the source of the fluid are ambiguous. PROCHASKA et al. (1997) studied fluids in quartz from several outcrops in the Eastern Alps by means of $\mathrm{O}$ and $\mathrm{H}$ isotopes, crush-leach analysis, and fluid inclusion microthermometry. They found that the fluids resemble the formation water of underlying nappes, sometimes with signatures of meteoric water. On the basis of $\mathrm{O}$ and $\mathrm{H}$ isotope studies on the leucophyllites from Sopron, DEMÉNy et al. (1997) argued that the fluids have a seawater origin. They concluded that the source of these fluids may be a hydrothermally-altered underlying oceanic crust.

The replacement of muscovite by paragonite (Figure $2 D$ ) is a unique feature in the leucophyllites of the Eastern Alps; this feature may be related to the later Na-bearing fluids discussed below.

3. Late stage $\mathrm{CO}_{2}$-bearing hypersaline fluids.

Fluid inclusion studies, and the $\mathrm{La}, \mathrm{Ce}, \mathrm{Nd}$, Th, $\mathrm{P}$ and $\mathrm{Al}$ content of opened inclusions revealed by EDS measurements, show that this type of fluid is responsible for precipitating a small-scale REE, Th and $\mathrm{P}$ mineralisation in the leucophyllites in the Füzes-árok. The minimum pressure limited by the widespread decrepitation — can be calculated approximately by the isochores of Type $1 \mathrm{CO}_{2}$ inclusions. The isochores of the most dense and the less dense $\mathrm{CO}_{2}$ inclusions indicated pressures between 190-430 MPa and temperatures between $400{ }^{\circ} \mathrm{C}$ and $600{ }^{\circ} \mathrm{C}$ (Figure 10).

Two observations provide evidence that the chemistry of the fluid changed with respect to space and time during the REE-Th-P mineralisation:

a) The REE-Th-P mineralisation has three distinct stages (florencite-type, monazite-type and allanite-type), characterised by the precipitation of different minerals. Florencite contains appreciable amounts of Al, which was carried by the same fluid as the REE, Th and P. The existence of the $\mathrm{Al}$ in the fluid was also evidenced by the SEM-EDS analysis of the fluid inclusion contents. Zoned florencites (Figure 2B) show the variation of the Th content in the fluids over time. Cheralite inclusions in florencite and the late cheralite fissure fillings also show temporal variations in Th deposition as well as the change in availability 
of $\mathrm{P}$ and $\mathrm{Al}$. Deformed florencites show that the process of deformation was continuously active during deposition of florencite. This deformation may have opened fractures and facilitated the fluid flow and deposition of cheralite after the florencite. In some places early florencite has been replaced by skeletal monazite crystals (Figure $2 C$ ). Idioblastic apatites which had grown on monazite (Figure $2 \mathrm{C}$ ) were also observed by FAZEKAS et al. (1975), and these showed the disappearance of REE and Th and the dominance of $\mathrm{Ca}$ within the fluid. Evidence of the precipitation of allanite in the quartz-tourmaline veins indicates the temporal absence of P. High amounts of $\mathrm{Ca}$ and $\mathrm{Fe}$ in the fluid are demonstrated by the iron content of allanite, the SEM-EDS analyses of opened fluid inclusions, and salt precipitates. Similar features - such as cracks in rock-forming minerals filled by monazite - were also observed by KERTÉSz et al. (2015).

b) Paragonitisation of muscovites (Figure 2D) took place only in monazite-apatite-type mineralisation. This kind of wall rock alteration requires an Na-rich fluid to substitute $\mathrm{K}$ in the muscovite, and it occurred exclusively during this stage of fluid influx. Paragonite formation was also observed in the micaschist in the pseudomorphs after staurolite. If this kind of fluid caused the breakdown of staurolites to paragonite-muscovite-albite \pm chloritoid \pm biotite aggregates in the Sopron micaschists, this means that it entered the host rock and caused retrograde metamorphic alterations. Some of the accessory monazite and apatite may not be inherited but precipitated from this fluid; this supposition is suggested by the hypersaline aqueous inclusions in the quartz grains of the rock matrix.

4. Retrograde saline $\mathrm{NaCl}-\mathrm{CaCl}_{2}-\mathrm{H}_{2} \mathrm{O}$ fluids.

This fluid belongs to the retrograde metamorphic development of the Sopron micaschist and postdates the Type 2 hypersaline $+\mathrm{CO}_{2}$ fluids, as evidenced by textural criteria described in the fluid inclusions section. Compositionally similar retrograde metamorphic fluid with a much lower homogenisation temperature and wider salinity range (13$29 \mathrm{wt} \%$ total salinity range) was also detected in the orthogneisses (TÖRÖK 2001). In this latter case there is no mineralogical evidence for fluid-rock interaction, unlike in some of the orthogneisses where late clinozoisite and epidote have been precipitated in the mylonitic parts of the rock (TöRÖK 1998). Isochores of $\mathrm{NaCl}-\mathrm{CaCl}_{2}-\mathrm{H}_{2} \mathrm{O}$ fluid inclusions partly overlap those of Type $1 \mathrm{CO}_{2}$ inclusions (Figure 10); this indicates similar trapping conditions. A summary of the P-T and fluid evolution of the Sopron micaschist is presented in the Figure 10.

\section{A comparison of Alpine fluids in the gneisses and in the Sopron micaschist}

In previous studies on fluid inclusions in the gneisses around Sopron, TÖRÖK $(1996,1998)$ described medium salinity (10.2 and $15.5 \mathrm{NaCl}$ eq. wt\%). He also noticed $\mathrm{NaCl}-$ dominated and medium to high salinity (13-29 wt $\%$ total salt content) $\mathrm{NaCl}-\mathrm{CaCl}_{2}-\left(\mathrm{MgCl}_{2}\right)-\mathrm{H}_{2} \mathrm{O}$ fluid inclusions. However, the fluids which circulated in the Sopron micaschist during Alpine retrogression are considerably different from the ones considered by TÖRÖK (2001). This suggests that either the fluid sources were different or the fluids interacted with the host rock, thus resulting in compositional changes. The latter supposition is backed up by the appearance of retrograde hypersaline fluids. The interaction of retrograde fluids with the host rock gave rise to more advanced retrograde rehydration reactions in the micaschist than in the orthogneiss; this process may have consumed a part of the water from the aqueous fluid, leaving behind a more concentrated brine. However, $\mathrm{CO}_{2}$-bearing fluids indicate other fluid sources such as, for example, decarbonation reactions or the migration of $\mathrm{CO}_{2}$ from deep sources during uplift.

\section{Conclusions}

Although the metamorphic rocks found in the Sopron Mts underwent high-pressure Alpine metamorphism, the calculated peak P-T conditions of the Sopron micaschist are lower than those obtained for other rock-types in the area. This can be attributed to the more retrogressed nature of the rock and to the fact that assemblages related with garnet cores were not suitable for geothermo-barometry.

Fluids found in the Sopron micaschist are considerably different from those in the orthogneiss (TöRÖK 2001).

1. In contrast to primary fluid inclusions in orthogneiss related to peak pressure conditions (TöRÖK 2001), the highest pressure fluids in the Sopron micaschist are related with tourmalinisation which occurred during the early stages of retrogression.

2. The formation of leucophyllitesis has been attributed to high salinity $\mathrm{NaCl}, \mathrm{CaCl}_{2}$ and $\mathrm{MgCl}_{2}$-rich aqueous fluids; this is similar to the leucophyllites which cross-cut orthogneisses and other micaschists of the Eastern Alps (ProCHASKA et al. 1997, TÖRÖK 2001), although fluid inclusions have not been found in the latter.

3. The Type 2 hypersaline $+\mathrm{CO}_{2}$ fluid may have (i) originated from a lower level of the nappe pile, (ii) dissolved REE elements, $\mathrm{P}$ and Th on its way up, (iii) precipitated florencite, monazite, cheralite and apatite in the shear zones of the upper level rock and (iv) caused rehydration reactions such as the breakdown of staurolite to paragonite and muscovite \pm chloritoid. The rehydration reactions resulted in $\mathrm{H}_{2} \mathrm{O}$ loss from the fluid and thus may be responsible for the increase in salinity. The REE+Th phosphate mineralisation may be correlated with lazulite $-\mathrm{Pb}$-bearing goyazite - apatite mineralisation; the latter has been described in connection with a leucophyllite cross-cutting orthogneiss in Sopron (TöRÖK 2001) and with the U-Th-REE-P mineralisation near Fertórákos (VINCZE et al. 1996). The main similarities between the above-described REE-Th-P and the lazulite-goyazite-apatite mineralisations are that (i) both mineralisations occurred in the leucophyllite, (ii) they postdate the leucophyllite formation and (iii) both mineralisations contain lazulite. Here it is important to mention that lazulite is a main component in the leucophyllite in the orthogneiss (TÖRÖK 2001) and a minor 
constituent in the REE-Th-P mineralisation (FAZEKAS et al. 1975). The dissimilarities are represented by the different mineralogy and the difference in fluid composition. The formation of lazulite $-\mathrm{Pb}$-bearing goyazite - apatite mineralisation can be attributed to a saline $\mathrm{NaCl}-\mathrm{CaCl}_{2}-\mathrm{H}_{2} \mathrm{O}$ fluid and the formation of the REE-Th-P mineralisation. The latter is linked with a $\mathrm{CO}_{2}$-bearing hypersaline aqueous fluid. However, $\mathrm{CO}_{2}$ is completely lacking from the fluids of the orthogneiss.

Late paragonitisation of muscovite in the studied leucophyllites had previously not been observed in leucophyllites from other localities. This feature shows a reintroduction of $\mathrm{Na}$, which had been removed earlier from the leucophyllitebearing shear zones by the metasomatising fluids responsible for the formation of leucophyllite (see TöRÖK 2001 for details).
4. High salinity $\mathrm{NaCl}-\mathrm{CaCl}_{2}-\mathrm{H}_{2} \mathrm{O}$ fluid inclusions are compositionally similar to the fluids which caused leucophyllite formation in the orthogneisses; however, these underwent considerably higher homogenisation temperatures and were trapped at lower pressures. These fluids were introduced later, compared to those which resulted in the formation of the leucophyllites.

\section{Acknowledgements}

The author would like to thank Dr. S. SZAKÁLL, Dr. Z. MÁTHÉ and Dr. S. JózSA for donating some of the tourmalinequartz veins, and REE and Th mineralised samples. The author also acknowledges the suggestions of the reviewer, which certainly improved the quality of the manuscript.

\section{References - Irodalom}

BAlOGH, K. \& DunKL, I. 2005: Argon and fission track dating of Alpine metamorphism and basement exhumation in the Sopron Mts. (Eastern Alps, Hungary): thermochronology or mineral growth? — Mineralogy and Petrology 83, 191-218. https://doi.org/10.1007/ s00710-004-0066-0

Berman, R. G. 1990: Mixing properties of Ca-Mg-Fe-Mn garnets. — American Mineralogist 75, 328-344.

DAVIS, D. W., LOWENSTEIN, T. K. \& SPENCER, R. J. 1990. Melting behavior of fluid inclusions in laboratory-grown halite crystals in the system $\mathrm{NaCl}-\mathrm{H}_{2} \mathrm{O}, \mathrm{NaCl}-\mathrm{KCl}-\mathrm{H}_{2} \mathrm{O}, \mathrm{NaCl}-\mathrm{MgCl}_{2}-\mathrm{H}_{2} \mathrm{O}$ and $\mathrm{NaCl}-\mathrm{CaCl}_{2}-\mathrm{H}_{2} \mathrm{O}$. - Geochimica et Cosmochimica Acta 54, 591-601. https://doi.org/10.1016/0016-7037(90)90355-o

DEMÉNY, A., SHARP, Z. D. \& PFEIFER, H-R. 1997: Mg metasomatism and formation conditions of Mg-chlorite-muscovite-quartzphyllites (leucophyllites) of the Eastern Alps (W. Hungary) and their relations to Alpine whiteschists. - Contributions to Mineralogy and Petrology128, 247-260. https://doi.org/10.1007/s004100050306

Dickenson, M. P. \& HewitT, D. 1986: A garnet-chlorite geothermometer. — Geological Society of America, Abstracts with Program 18, p. 584.

DraGanits, E. 1998: Two crystalline series of the Sopron Hills (Burgenland) and their correlation to the lower Austroalpine in Eastern Austria. - Jahrbuch der Geologischen Bundesanstalt 141, 113-146. (in German with English abstract).

FAZEKAS V., KóSA L. \& SELMECZI B. 1975: Ritkaföldfém ásványosodás a Soproni-hegység kristályos paláiban. (Rare-earth element mineralisation in the crystalline schists of the Sopron Mountains.) - Földtani Közlöny105, 297-308. (in Hungarian with English abstract).

FERRY, J. M. \& SPEAR, F. S. 1978. Experimental calibration of the partitioning of Fe and Mg between biotite and garnet. —Contributions to Mineralogy and Petrology 66, 113-117. https://doi.org/10.1007/bf00372150

Green, T. H. \& Hellman, P. L. 1982: Fe-Mg partitioning between coexisting garnet and phengite at high pressure and comments on a garnet-phengite geothermometer. — Lithos 15, 253-266. https://doi.org/10.1016/0024-4937(82)90017-2

Gregurek, D., Abart, R. \& Hoinkes, G. 1997: Contrasting Eoalpine P-T evolutions in the southern Koralpe, Eastern Alps. Mineralogy and Petrology 60, 61-80. https://doi.org/10.1007/bf01163135

Hodges, K. V. \& Crowley, P. D. 1985: Error estimation and empirical geothermobarometry for pelitic systems. - American Mineralogist 70, 702-709.

Kertész, Zs., Furu, E., AngYal, A., Freiler, Á., TöröK, K. \& HorvÁth, Á. 2015: Characterization of uranium and thorium containing minerals by nuclear microscopy. — Journal of Radioanalytical and Nuclear Chemistry 306, 283-288. https://doi.org/10.1007/s10967015-4175-5

Kisházi, P. \& IVANCSICS, J. 1985: Genetic petrology of the Sopron Crystalline schist sequence. — Acta Geologica Hungarica 28, 191213.

KIsHÁzi P. \& IVANCSICS J. 1987: A Soproni Csillámpala Formáció genetikai kőzettana.(Genetic petrology of the Sopron Micaschist Formation.) - Földtani Közlöny 117, 203-221. (in Hungarian with English abstract).

KisházI, P. \& IVAnCSICS, J. 1989: A Soproni Gneisz Formáció genetikai kőzettana. (Petrogenesis of the Sopron Gneiss Formation.) — Földtani Közlöny 119, 153-166.

Lelkes-Felvári, Gy., SASSI, F. P. \& VisonÁ, D. 1984: Pre-Alpine and Alpine developments of the Austridic basement in the Sopron area (Eastern Alps, Hungary). — Rendiconti della Società Italiana di Mineralogia e Petrologia 39, 593-612. 
MiLLER, C. 1990: Petrology of the type locality eclogites from the Koralpe and Saualpe (Eastern Alps) Austria. — Schweizerische Mineralogische und Petrographische Mitteilungen 70, 287-300.

NAGY, G., Draganits, E., DEMÉNY, A., PANTÓ, Gy. \& ÁRKAI, P. 2002: Genesis and transformations of monazite, florencite and rhabdophane during medium grade metamorphism:examples from the Sopron Hills, Eastern Alps. — Chemical Geology 191/1-3, 25-46. https://doi.org/10.1016/s0009-2541(02)00147-x

Neubauer, F., DAllmeYer, R. D. \& TAKASU, A. 1999: Conditions of eclogite formation and age of retrogression within the Sieggraben unit, Eastern Alps: Implications for Alpine-Carpathian tectonics. —Schweizerische Mineralogische und Petrographische Mitteilungen 79, 297-307.

OAKes, C. S., Bodnar, R. J. \& Simonson, T. M. 1990: The system $\mathrm{NaCl}-\mathrm{CaCl}_{2}-\mathrm{H}_{2} \mathrm{O}$ : I. The ice liquidus at 1 atm total pressure. Geochimica et Cosmochimica Acta 54, 603-610. https://doi.org/10.1016/0016-7037(90)90356-p

OlsEn, S. N. 1987: The composition and role of the fluid in migmatites: a fluid inclusion study of the Front Range rocks. Contributions to Mineralogy and Petrology 96, 104-120. https://doi.org/10.1007/bf00375531

Prochaska, W., Huber, M. \& Bechtel, A.1997: Alpidic formation of leucophyllite at the eastern margin of the Alps. - Archiv für Lagerstättenforschung der Geologischen Bundesanstalt 20, 37-52. (in German with English abstract).

SCHuster, R. \& ThÖNI, M. 2001: Austroalpine basement units (AAB). — In: DunKL, I., BALINTONI, I., Frisch, W., JANÁK, M., KoRoKNAI, B., Milovanovic, D., PAmic, J., SzÉKely, B. \& VRabec, M. (eds): Metamorphic map and database of Carpatho-Balkan-Dinaride area. http://www.met-map.uni-goettingen.de

SPRÁnitz, T., JózSA, S., KovÁcs, Z., VÁcZI, B. \& TöRÖK, K. 2018: Magmatic and metamorphic evolution of tourmaline-rich rocks of the Sopron area, Eastern Alps. — Journal of Geosciences 63, 175-191. https://doi.org/10.3190/jgeosci.263

TнӧNI, M. 1999: A review of geochronological data from the Eastern Alps. - Schweizerische Mineralogische und Petrographische Mitteilungen 79, 209-230.

Tollmann, A. 1977: Geologie von Österreich. Band I. Die Zentralalpen. — Deuticke, Vienna, 766 p.

ТӧRÖK, K. 1996: High-pressure/low temperature metamorphism of the Kő-hegy gneiss, Sopron (W-Hungary); Phengite barometry and fluid inclusions. — European Journal of Mineralogy 8, 917-925. https://doi.org/10.1127/ejm/8/5/0917

TÖRÖK, K. 1998: Magmatic and high-pressure metamorphic development of orthogneisses in the Sopron area, Eastern Alps (W Hungary) — Neues Jahrbuch für Mineralogie Abhandlungen 173, 63-91.

TÖRÖK, K. 1999: Pre-Alpine development of the andalusite-sillimanite-biotite-schist from the Sopron-Mountains (Eastern Alps, W Hungary). - Acta Geologica Hungarica 42, 127-160.

TӧвÖK, K. 2001: Multiple fluid migration events in the Sopron Gneisses during the Alpine high-pressure metamorphism, as recorded by bulk-rock and mineral chemistry and fluid inclusions. - Neues Jahrbuch für Mineralogie Abhandlungen 177/1, 1-36. https://doi.org/10.1127/007777502753418566

TöRÖK, K. 2003: Alpine P-T path of micaschists and related orthogneiss veins near Óbrennberg (W Hungary, Eastern Alps). — Neues Jahrbuch für Mineralogie Abhandlungen 179, 101-142. https://doi.org/10.1127/0077-7757/2003/0179-0101

VANKo, D. A., BoDnAR, R. J. \& STERnER, M. A. 1988: Synthetic fluid inclusions: VIII. Vapor saturated halite solubility in part of the system $\mathrm{NaCl}-\mathrm{CaCl}_{2}-\mathrm{H}_{2} \mathrm{O}$, with application to fluid inclusions from oceanic hydrothermal systems. — Geochimica et Cosmochimica Acta 52, 2451-2456. https://doi.org/10.1016/0016-7037(88)90303-1

VINCZE,J., FAZEKAS V. \& KóSA L. 1996: A fertőrákosi kristályospala összlet urán-tórium-ritkaföldfém és szulfidos ásványosodásai. (Uranium-thorium-rare earth mineralisations in the crystalline schist series, Fertőrákos, Sopron Mts., NW Hungary.) — Földtani Közlöny 126, 359-417. (in Hungarian with English Abstract)

WANG, P. \& SPEAR, F. S. 1991. A field and theoretical analysis of garnet+chlorite+chloritoid+biotite assemblages from the tri-state (MA, CT, NY) area, USA. - Contributions to Mineralogy and Petrology106, 217-235. https://doi.org/10.1007/bf00306435

Yanatieva, O. K. 1946: Polythermal solubilities in the systems $\mathrm{CaCl}_{2}-\mathrm{MgCl}_{2}-\mathrm{H}_{2} \mathrm{O}$ and $\mathrm{CaCl}_{2}-\mathrm{NaCl}_{2} \mathrm{H}_{2} \mathrm{O}$. Z Zhurnal Prikladnoi Khimii 19, 709-722. (in Russian).

Manuscript recieved: 03/07/2019 